Article

\title{
Design, Synthesis of New 1,2,4-Triazole/1,3,4-Thiadiazole with Spiroindoline, Imidazo[4,5-b]quinoxaline and Thieno[2,3-d]pyrimidine from Isatin Derivatives as Anticancer Agents
}

\author{
Ameen Ali Abu-Hashem 1,2,*(i) and Sami A. Al-Hussain ${ }^{3}$ \\ Heterocyclic Unit, Photochemistry Department, National Research Centre, Dokki, Giza 12622, Egypt \\ Chemistry Department, Faculty of Science, Jazan University, Jazan 45142, Saudi Arabia \\ 3 Department of Chemistry, Faculty of Science, Imam Mohammad Ibn Saud Islamic University (IMSIU), \\ Riyadh 13318, Saudi Arabia; sahussain@imamu.edu.sa \\ * Correspondence: aminaliabuhashem@yahoo.com; Tel.: +20-012-2521-1700; Fax: +20-2-3337-0931
}

check for

updates

Citation: Abu-Hashem, A.A.;

Al-Hussain, S.A. Design, Synthesis of New 1,2,4-Triazole/1,3,4-Thiadiazole with Spiroindoline, Imidazo[4,5-b]qui noxaline and Thieno[2,3-d]pyrimidine from Isatin Derivatives as Anticancer Agents. Molecules 2022, 27, 835. https://doi.org/10.3390/ molecules 27030835

Academic Editor: Helen Osborn

Received: 30 December 2021

Accepted: 17 January 2022

Published: 27 January 2022

Publisher's Note: MDPI stays neutral with regard to jurisdictional claims in published maps and institutional affiliations.

Copyright: (C) 2022 by the authors. Licensee MDPI, Basel, Switzerland. This article is an open access article distributed under the terms and conditions of the Creative Commons Attribution (CC BY) license (https:// creativecommons.org/licenses/by/ $4.0 /)$.

\begin{abstract}
The current work aims to design and synthesis a new series of isatin derivatives and greatly enhances their cytotoxic activity. The derivatives 3-((bromophenyl) imino)-1-(morpholino (pyridine) methyl) indolin-2-one, 2-((oxoindoline) amino) benzoic acid, 3-(thiazolo-imino) indolinone, ethyl-2((oxoindolin-3-ylidene)amino)-benzothiophene-3-carboxylate, 1-(oxoindoline)-benzo[4,5] thieno [2,3d]pyrimidin-4(1H)-one, ethyl-2-(2-oxoindoline) hydrazine-1-carboxylate, $\mathrm{N}$-(mercapto-oxo-pyrimidine)-2(oxoindoline) hydrazine-1-carboxamide, $\mathrm{N}$-(oxo-thiazolo[3,2-a] pyrimidine)-2-(oxoindolin-ylidene) hydrazine-carboxamide, 3-((amino-phenyl) amino)-3-hydroxy- indolinone, 3-((amino-phenyl) imino)indolinone, 2-(2-((oxoindoline) amino) phenyl) isoindolinone, 2-(oxoindoline) hydrazine-carbothioamide, $5^{\prime}$-thioxospiro[indoline-3,3' -[1,2,4]triazolidin]-one, $5^{\prime}$-amino-spiro[indoline-3,2' -[1,3,4]thiadiazol]-2one and 3-((2-thioxo-imidazo[4,5-b]quinoxaline) imino) indolinone were synthesized from the starting material 1-(morpholino (pyridine) methyl) indoline-2,3-dione and evaluated for their in vitro cytotoxic activity against carcinogenic cells. The new chemical structures were evidenced using spectroscopy (IR, NMR and MS) and elemental analysis. The results show that compounds imidazo[4,5-b]quinoxaline-indolinone, thiazolopyrimidine-oxoindoline, pyrimidine-oxoindolinehydrazine-carboxamide, spiro[indoline- $3,2^{\prime}$-[1,3,4] thiadiazol]-one and spiro[indoline-3,3'-[1,2,4]triazo lidin]-one have excellent anti-proliferative activities against different human cancer cell lines such as gastric carcinoma cells (MGC-803), breast adenocarcinoma cells (MCF-7), nasopharyngeal carcinoma cells (CNE2) and oral carcinoma cells (KB).
\end{abstract}

Keywords: thioxo-spiroindoline; isoindolinone; isatin; triazole; thiadiazole; hydrazine; thiazole; pyrimidine; imidazole; quinoxaline; anti-proliferative; cytotoxic activity

\section{Introduction}

Recently, cancer has been spreading among people at a high rate. Thus, cancer is one of the main causes of death. In 2017, the death of nearly 9.6 million people due to different types of cancer made it the second leading cause of death, second only to cardiovascular diseases [1,2].

Hence, in the last decade, many researchers have worked to prepare various heterocyclic compounds that are used in the treatment of most cancer cells in the human body. For instance, isatin derivatives are an interesting category of heterocyclic molecules that have different biological and pharmacological activities [3].

In addition, spiro compounds have been showing distinguished pharmacological activity, especially in the chemistry of natural products. Many studies have been demonstrating the synthesis of spiro derivatives of isatin at the $(\mathrm{C}-3)$ position as $\alpha$-methylene 
$\gamma$-butyrolactone spirocyclic, which is derived from isatin and is the proper core for optimization to identify new anticancer agents [4]. The spiro pyrazole-oxindole analogues are considered as valuable anticancer agents against human cancer cells [5].

Furthermore, the oxindolylidene acetate derivatives showed potent anticancer activities against a diversity of human cancer cell lines [6]. The indoline-2,3-dione moiety is a significant constituent of many pharmaceutically essential compounds such as sunitinib and hesperidin.

In a recent study, the researchers widely explored isatin derivatives in several clinically approved anticancer drugs, including Sunitinib (A), Toceranib phosphate (B), and 5-Substituted isatin hydroxamic acid (C). These derivatives are used as histone deacetylase (HDAC enzyme) inhibitors and possess anti-proliferative activities against cervical tumor cell lines $[7,8]$, shown in (Figure 1).<smiles>[R]c1ccc2c(c1)/C(=N/NC(=S)NCC(=O)NO)C(=O)N2CCNC(=O)c1c(C)[nH]c(/C=C2\C(=O)Nc3ccc(F)cc32)c1C</smiles>

Figure 1. Anticancer drugs: Sunitinib (A), Toceranib phosphate (B), substituted isatin-hydroxamic acid $(\mathbf{C})$ derived from isatin derivatives.

Moreover, scientific articles have confirmed that isatin derivatives such as the rhinoviruses [9], vaccinia virus [10], poxvirus [11], SARS virus [12,13] and Moloney leukemia virus [14] have antiviral activities. Recently, the isatin-thiazoline hybrids (D) have been shown to contain inhibitors of HIV-1 reverse transcriptase (RT) [15], isatin-hydrazine1-carbothioamide (E) has shown anti-CVB3 activity [16], and isatin- $\beta$-thiosemicarbazone hybrids with imidazoles (MBZM- N-IBT) have been show to possess the antiviral activities against the chikungunya virus (CHIKV) [17], shown in (Figure 2).<smiles>[R][X]c1cccc(-c2cs/c(=N/N=C3\C(=O)Nc4ccc([X])cc43)n2C)c1</smiles>

(D)<smiles>NC(=S)N/N=C1/C(=O)Nc2ccccc21</smiles>

(E)<smiles>Cc1nc2ccccc2n1CN1C(=O)/C(=N/NC(N)=S)c2ccccc21</smiles>

MBZM-N-IBT

Figure 2. Anti-viral drugs: isatin-thiazoline hybrids (D), isatin-hydrazine-1-carbothioamide (E), isatin- $\beta$-thiosemicarbazone hybrids- imidazoles (MBZM- N-IBT) from isatin derivatives. 
Furthermore, isatin's importance has been promoted by the discovery of a number of new anti-tubercular agents [18], and a series of 1,2,3-triazole-isatin combined with ciprofloxacin represented anti-mycobacterial activity [19]. Furthermore, heterocyclic compounds containing heteroatoms such as $O, S$ and $N$ were considered effective inhibitors against the corrosion of steel in acidic media [20]. Hence, isatin derivatives and Mannich bases showed they are inhibitors against aluminum and steel corrosion [21].

Based on the above, isatin continues to be one of the more researched areas in synthetic and medicinal chemistry, aiding us in continuing our research work on the synthesis and design of biologically and pharmacological active heterocyclic compounds [22-50].

Thus, we introduce and evidence in this manuscript the synthesis of several isatin derivatives including morpholinopyridine-(thiazole-imino) indolinone; benzo[4,5]thieno [2,3-d]pyrimidinone; hydrazine-carboxylate; hydrazine-carboxamide; thiazolo[3,2-a]pyrimidine; amino-iminoindolinone; thioxospiro[indoline-3,3'-[1,2,4]triazolidin]-one; spiro [indoline-3,2'-[1,3,4]thiadiazol]-2-one; and 3-((2-thioxo-imidazo[4,5-b]quinoxaline)imino) indolinone using recent procedures. The synthesized compounds were studied in vitro to evaluate their anticancer activity against different human cancer cell lines.

\section{Results and Discussion}

\subsection{Synthesis}

In order to perform one-pot synthesis using Mannich bases reaction [51-53], we synthesized 1-(morpholino (pyridin-4-yl) methyl) indoline-2, 3-dione (2) in excellent yield through stirring and refluxing a mixture of isatin (1) with freshly distilled secondary aliphatic amine as morpholine and isonicotinaldehyde in sodium ethoxide solution at room temperature under control (TLC). The IR spectrum compound (2) showed absorption bands at $v 1735$ and $1680 \mathrm{~cm}^{-1}$ conforming to two carbonyl groups. ${ }^{1} \mathrm{H}-\mathrm{NMR}$ spectrums of (2) revealed multiplet signals at $\delta 2.60-3.05 \mathrm{ppm}$ corresponding to eight protons of morpholine and one singlet at $\delta 6.72 \mathrm{ppm}$ corresponding to one proton of methine proton.

The ${ }^{13} \mathrm{C}$-NMR spectrum of (2) displayed absorption signals at $\delta 51.2$ and $58.8 \mathrm{ppm}$ conforming to four carbon atoms of the $\left(4 \mathrm{CH}_{2}\right)$ morpholine and $95.4 \mathrm{ppm}$ corresponding to one carbon atom of the methine proton $(\mathrm{CH})$ group.

In continuation of our research plan in exploring the reactivity of isatin derivatives, we were interested in preparing 3-substituted-indolin-2-one, as expected as anticancer scaffolds. Therefore, syntheses of (3-5) started from 1- (morpholino (pyridin-4-yl) methyl) indoline2,3-dione (2) through activation of the $\mathrm{C}_{3}$-substituted isatin, which is a carbonyl group, as a good leaving group with the exit water molecule as a requirement for the subsequent $\mathrm{SNAr}$ (nucleophilic aromatic substitution) reaction to occur with weak $N$-nucleophiles such as $\mathrm{NH}_{2}$-heterocycles. Moreover, compound (2) reacted with 4-bromo aniline in methanolic potassium hydroxide solution to yield 3-((4-bromophenyl) imino)-1- (morpholino (3yridine4-yl) methyl) indolin-2-one (3).

Furthermore, condensation of compound (2) with 2-aminobenzoic acid and anhydrous potassium carbonate in dry dimethylformamide afforded 2-((1-(morpholino (pyridin3-4-yl) methyl)-2-oxoindolin-3-ylidene) amino) benzoic acid (4).

In addition, condensation of compound (2) with 2-aminothiazole and anhydrous potassium carbonate in dry dimethylformamide yielded 1-(morpholino (3yridine-4-yl) methyl)-3-(thiazol-2-ylimino) indolin-2-one (5). The IR spectrum of (3) showed absorption bands at $v 1688 \mathrm{~cm}^{-1}$ for the one carbonyl group, and the ${ }^{13} \mathrm{C}-\mathrm{NMR}$ spectrum of 3 revealed absorption signals at $\delta 51.5$ and 58.9 ppm corresponding to four carbon atoms of the $\left(4 \mathrm{CH}_{2}\right)$ morpholine, at $\delta 94.7 \mathrm{ppm}$ corresponding to one carbon atom of the methine proton $(\mathrm{CH})$ group and at $\delta 164.1 \mathrm{ppm}$ conforming to one carbonyl group.

Likewise, the IR spectrum of (4) indicated absorption bands at $v 3750 \mathrm{~cm}^{-1}$ for the one hydroxyl group and at $v 1740$ and $1688 \mathrm{~cm}^{-1}$ for two carbonyl groups, and the ${ }^{1} \mathrm{H}-\mathrm{NMR}$ spectrum of (4) evidenced one singlet signal at $\delta 12.60 \mathrm{ppm}$ for the one proton of $(\mathrm{OH})$ group $\left(\mathrm{D}_{2} \mathrm{O}\right.$ exchangeable). The ${ }^{13} \mathrm{C}$-NMR spectrum of (4) exposed absorption signals at $\delta$ 52.2 and $59.1 \mathrm{ppm}$ matching four carbon atoms of the $\left(4 \mathrm{CH}_{2}\right)$ morpholine, at $\delta 95.3 \mathrm{ppm}$ 
corresponding for one carbon atom of the methine proton $(\mathrm{CH})$ group and at $\delta 164.7$ and $167.1 \mathrm{ppm}$ corresponding to two carbonyl groups.

Similarly, ${ }^{1} \mathrm{H}-\mathrm{NMR}$ spectrums of (5) discovered multiplet signals at $\delta 2.72-3.18 \mathrm{ppm}$ conforming to eight protons of morpholine, one singlet at $\delta 6.67 \mathrm{ppm}$ corresponding to one proton of methine proton and two doublet signals at $\delta 7.78$ and $7.85 \mathrm{ppm}$ corresponding for two protons of $(J=6.92 \mathrm{~Hz})$ thiazole ring. The ${ }^{13} \mathrm{C}-\mathrm{NMR}$ spectrum of (5) demonstrated absorption signals at $\delta 52.5$ and $59.7 \mathrm{ppm}$ corresponding to four carbon atoms of the $\left(4 \mathrm{CH}_{2}\right)$ morpholine, at $94.4 \mathrm{ppm}$ corresponding to one carbon atom of the methine proton $(\mathrm{CH})$ group and at $\delta 168.2 \mathrm{ppm}$ conforming to one carbonyl group.

The mass spectra of $\left(\mathbf{2}, 3,4\right.$ and 5) evidenced molecular ion peaks at $m / z=323\left(\mathrm{M}^{+}\right.$, $100 \%), 477\left(\mathrm{M}^{+}, 100 \%\right), 442\left(\mathrm{M}^{+}, 100 \%\right)$ and $405\left(\mathrm{M}^{+}, 100 \%\right)$, respectively. IR, NMR, MS and elemental analysis are elucidated in the experimental section for new compounds and shown in (Scheme 1).<smiles>O=C1C(=O)N(C(c2ccncc2)N2CCOCC2)c2ccccc21</smiles>

$2(85 \%)$<smiles>O=C1C(=O)N(C2CCCCC2)c2ccccc21</smiles>

isonicotinaldehyde

morpholine<smiles>Nc1ccc(Br)cc1</smiles><smiles>O=C1Nc2ccccc2/C1=N/c1ccc(Br)cc1</smiles>

$10-12 \mathrm{~h}$<smiles>CC(c1ccncc1)N1CCOCC1</smiles><smiles>O=C(O)c1ccccc1/N=C1\C(=O)N(C(c2ccncc2)(N2CCOCC2)N2CCOCC2)c2ccccc21</smiles><smiles>Nc1nccs1</smiles><smiles>O=C1/C(=N\c2nccs2)c2ccccc2N1C(c1ccncc1)N1CCOCC1</smiles>

Scheme 1. Synthesis of 1-(morpholino (pyridine) methyl)-2-oxoindoline) amino) and thiazole derivatives via condensation and Mannich bases reaction.

Furthermore, we synthesized isatin with benzo[4,5]thieno[2,3-d]pyrimidine, hydrazine1-carboxamide and thiazolo[3,2-a]pyrimidine moieties by nucleophilic aromatic substitution and condensation reactions and study of the cytotoxicity of synthesized compounds against human different carcinoma cell lines in vitro.

Furthermore, the compound (2) reacted with ethyl 2-amino-4,5,6,7-tetrahydro benzo[b] thiophene-3-carboxylate in refluxing dimethylformamide with the presence of potassium carbonate afforded ethyl-2-((1-(morpholino (pyridin-4-yl) methyl)-2-oxoind- olin- 
3-ylidene) amino)-4,5,6,7-tetrahydrobenzo[b] thiophene-3-carboxylate (6). The IR spectrum of (6) indicated the presence of absorption bands at $v 1775$ and $1682 \mathrm{~cm}^{-1}$ conforming for two carbonyl groups. The ${ }^{1} \mathrm{H}$ NMR spectrum of (6) displayed multiplet signals at $\delta=1.08-1.15 \mathrm{ppm}$ for eight protons of $\left(4 \mathrm{CH}_{2}\right.$, cyclohexane), multiplet signals at $\delta=2.75-3.22 \mathrm{ppm}$ for eight protons of $\left(4 \mathrm{CH}_{2}\right.$, morpholine $)$, and one singlet signal at $\delta=6.62 \mathrm{ppm}$ for one proton of methine proton $(\mathrm{CH})$ group.

Furthermore, the latter compound (6) reacted with formamide in dimethylformamide with the presence of potassium carbonate for a long time under control (TLC) to yield 1-(1(morpholino(pyridin-4-yl)methyl)-2-oxoindolin-3-yl)-5,6,7,8-tetrahydrobenzo [4,5]thieno [2,3-d]pyrimidin-4(1H)-one (7). The $1 \mathrm{H}-\mathrm{NMR}$ spectrum of (7) exhibited two singlets at $\delta=5.10$ and $8.15 \mathrm{ppm}$, corresponding to the one proton of pyrrole and one proton of pyrimidine ring, respectively.

Moreover, condensation of compound (2) with ethyl hydrazinecarboxylate in boiling dimethylformamide and potassium carbonate produced Ethyl-2-(1-(morpholino (pyridin4-yl) methyl)-2-oxoindolin-3-ylidene) hydrazine-1-carboxylate (8). The IR spectrum of 8 showed the presence of broad band absorption at $v 3325 \mathrm{~cm}^{-1}$ for one (NH) group and two peaks in absorption at $v 1691$ and $1684 \mathrm{~cm}^{-1}$ for two carbonyl groups, and the ${ }^{1} \mathrm{H}-\mathrm{NMR}$ spectrum of (8) displayed a broad singlet at $\delta 10.50 \mathrm{ppm}$ corresponding to the one proton of $(\mathrm{NH})$ group exchangeable with $\mathrm{D}_{2} \mathrm{O}$.

Furthermore, the treatment of the same compound (8) with 6-amino-2-mercaptopyrimidin- $4(3 H)$-one in refluxing and stirring dimethylformamide and an amount of TEA $(0.5 \mathrm{~mL})$ as catalysis produced $N$-(2-mercapto-6-oxo-1,6-dihydropyrimidin-4-yl)-2(1-(morpholi- no (pyridin-4-yl) methyl)-2-oxoindolin-3-ylidene) hydrazine-1-carboxami- de (9). The IR spectrum of (9) displayed three peaks in broad band absorption at $v 3330-3270 \mathrm{~cm}^{-1}$ corresponding to three (3NH) groups and three peaks in absorption at $v 1695,1688$ and 1682 corresponding to three carbonyl groups, and ${ }^{1} \mathrm{H}-\mathrm{NMR}$ spectrum of (9) exhibited three broad singlets at $\delta 9.90,10.80$ and $11.70 \mathrm{ppm}$ corresponding to the three protons of three $(3 \mathrm{NH})$ exchangeable with $\mathrm{D}_{2} \mathrm{O}$.

Otherwise, condensation of the later compound (9) with chloroacetic acid in a mixture of glacial acetic acid and glacial acetic anhydride in the presence of anhydrous sodium acetate under stirring and refluxing led to $\mathrm{N}$-(3,5-dioxo-2,3-dihydro- $5 \mathrm{H}$-thiazolo[3, 2a]pyrimidin-7-yl)-2-(1-(morpholino(pyridin-4-yl)methyl)-2-oxoindolin-3-ylidene)hydr- azine1-carboxamide (10). IR spectrum of (10) showed absorption broadband at $v 3325-3280 \mathrm{~cm}^{-1}$ conforming to two (2NH) groups and four peaks at $v 1691,1686,1681$ and $1675 \mathrm{~cm}^{-1}$ for four carbonyl groups, and ${ }^{1} \mathrm{H}-\mathrm{NMR}$ spectrum of (10) exposed two broad singlets at $\delta$ 10.10 and $11.60 \mathrm{ppm}$ corresponding to the two protons of two $(2 \mathrm{NH})$ groups exchangeable with $\mathrm{D}_{2} \mathrm{O}$.

MS spectrum of $(\mathbf{6}, 7, \mathbf{8}, \mathbf{9}$ and 10$)$ revealed molecular ion peaks at $m / z=530\left(\mathrm{M}^{+}\right.$, $100 \%), 513\left(\mathrm{M}^{+}, 95 \%\right), 409\left(\mathrm{M}^{+}, 100 \%\right), 409\left(\mathrm{M}^{+}, 100 \%\right)$ and $546\left(\mathrm{M}^{+}, 92 \%\right)$, respectively. Correct new chemical structures were approved of through spectroscopic, IR, ${ }^{1} \mathrm{H},{ }^{13} \mathrm{C}$, -NMR, mass spectra and elemental analysis, shown in (Exp. Part and Schemes 2 and 3).

We report here the synthesis of new 3-((2-aminophenyl) amino)-indolin-2-one, 3-((2amino-phenyl) imino)-indolin-2-one and 2-((amino) phenyl) isoindoline-1, 3-dione and describe their anticancer properties.

Furthermore, the reaction of (2) with benzene-1, 2-diamine in methanol and diethyl amine with stirring and refluxing afforded 3-((2-aminophenyl) amino)-3-hydroxy1-(morpholino (pyridin-4-yl) methyl) indolin-2- one (11). Its IR of (11) shows three broad peaks at $v 3415,3370$ and $3330 \mathrm{~cm}^{-1}$ corresponding to $\left(\mathrm{NH}_{2}\right),(\mathrm{OH})$ and $(\mathrm{NH})$ groups, respectively, and a sharp intensity in one peak at $v 1682 \mathrm{~cm}^{-1}$ corresponding to one carbonyl group. The ${ }^{1} \mathrm{H}-\mathrm{NMR}$ spectrum of (11) contains three broad signals at $\delta 6.25,11.10$ and $12.60 \mathrm{ppm}$ for two protons $\left(\mathrm{NH}_{2}\right)$, one proton $(\mathrm{NH})$ and one proton $(\mathrm{OH})$ groups exchangeable with $\mathrm{D}_{2} \mathrm{O}$, respectively.

Furthermore, stirring and refluxing of the same compound (11) in glacial acetic acid with concentrated $\mathrm{HCl}$ under (TLC) control afforded 3-((2-aminophenyl)imino)-1- 
(morpholi- no (pyridin-4-yl) methyl) indolin-2-one (12) in good yield. The IR spectrum compound (12) exhibited absorption bands at $v 3410 \mathrm{~cm}^{-1}$ corresponding to $\mathrm{NH}_{2}$ group and1684 $\mathrm{cm}^{-1}$ corresponding to one carbonyl group. ${ }^{1} \mathrm{H}-\mathrm{NMR}$ spectrum of (12) revealed one singlet at $\delta 6.35 \mathrm{ppm}$ conforming to two protons of $\mathrm{NH}_{2}$ group $\left(\mathrm{D}_{2} \mathrm{O}\right.$ exchangeable).

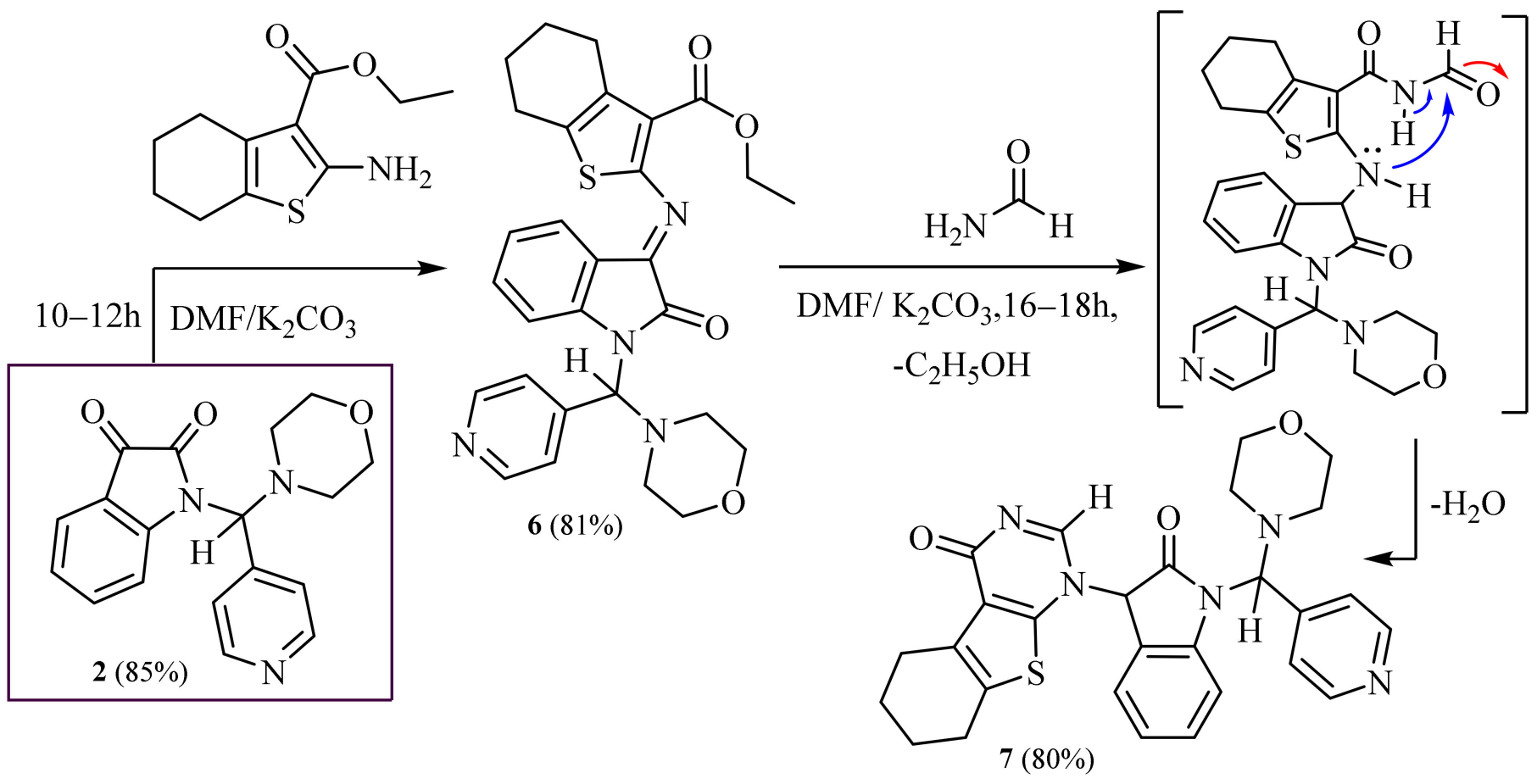

Scheme 2. Synthesis of 2-oxoindoline- benzo $[4,5]$ thieno $[2,3-\mathrm{d}]$ pyrimidinones.

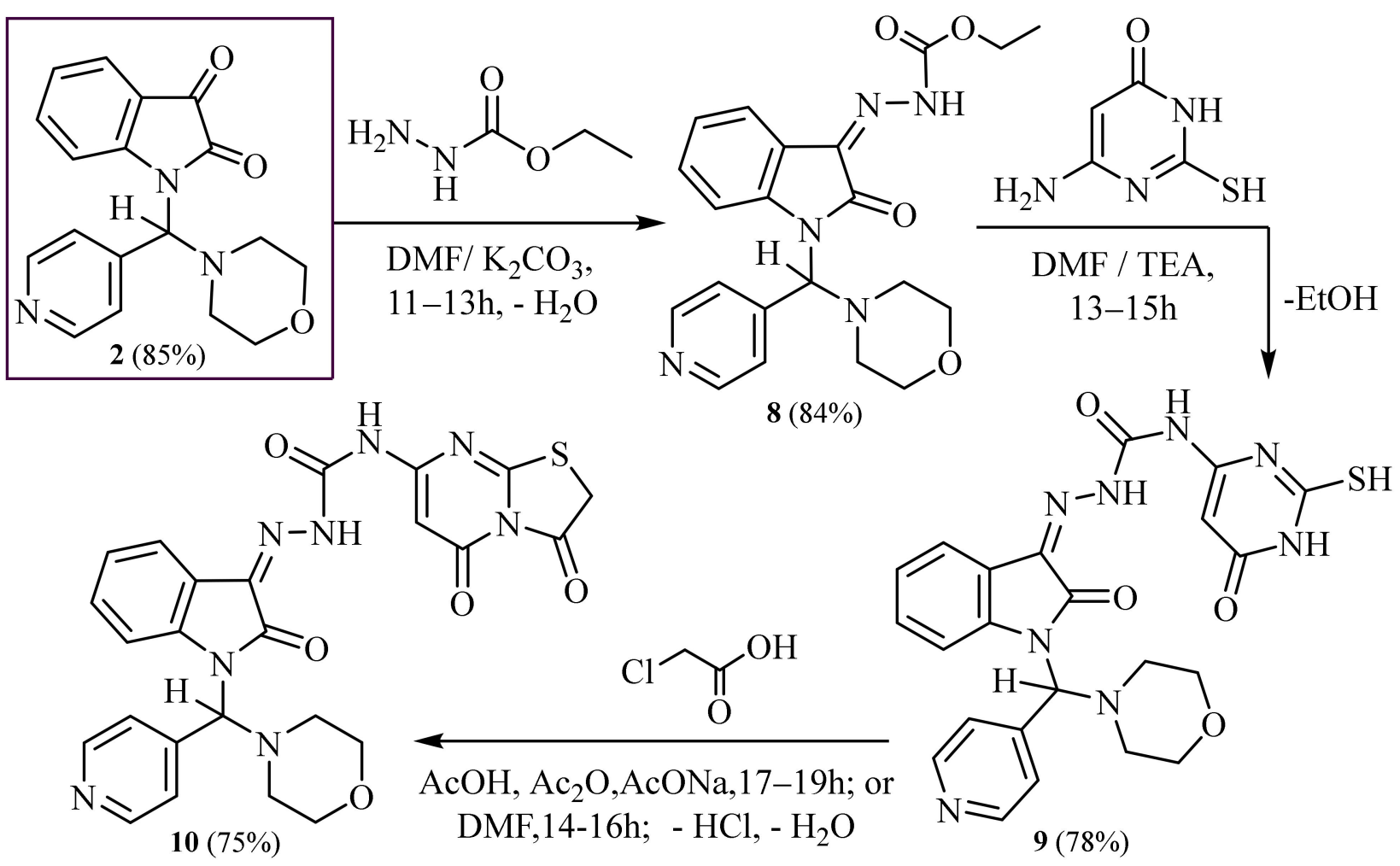

Scheme 3. Synthesis of thiazolo [3,2-a] pyrimidine,-hydrazine-1-carboxamide with isatin. 
Moreover, treatment of the latter compound (12) with phthalic anhydrides in absolute methanol containing a few drops of glacial acetic acid afforded 2-(2-((1-(morpho- lino (pyridin-4-yl) methyl)-2-oxoindolin-3-ylidene) amino) phenyl) isoindoline-1, 3-dione (13) in good yield. IR spectrum of (13) showed absorption bands at $v 1688,1682$ and $1677 \mathrm{~cm}^{-1}$ for three carbonyl groups. The ${ }^{13} \mathrm{C}-\mathrm{NMR}$ spectrum of (13) exhibited absorption signals at $\delta 52.3$ and $59.1 \mathrm{ppm}$, corresponding to four carbon atoms of $\left(4 \mathrm{CH}_{2}\right.$, morpholine), at $\delta$ $93.8 \mathrm{ppm}$ for methine proton $(\mathrm{CH})$ group and at $\delta 166.1,168.5 \mathrm{ppm}$ for three carbon atoms of the three carbonyl groups.

The mass spectra of $\left(\mathbf{1 1}, \mathbf{1 2}\right.$ and 13) evidenced molecular ion peaks at $m / z=431\left(\mathrm{M}^{+}\right.$, $90 \%), 413\left(\mathrm{M}^{+}, 100 \%\right)$ and $543\left(\mathrm{M}^{+}, 100 \%\right)$, respectively. IR, NMR, MS and elemental analysis were explicated in the experimental section for all compounds and shown in (Scheme 4).
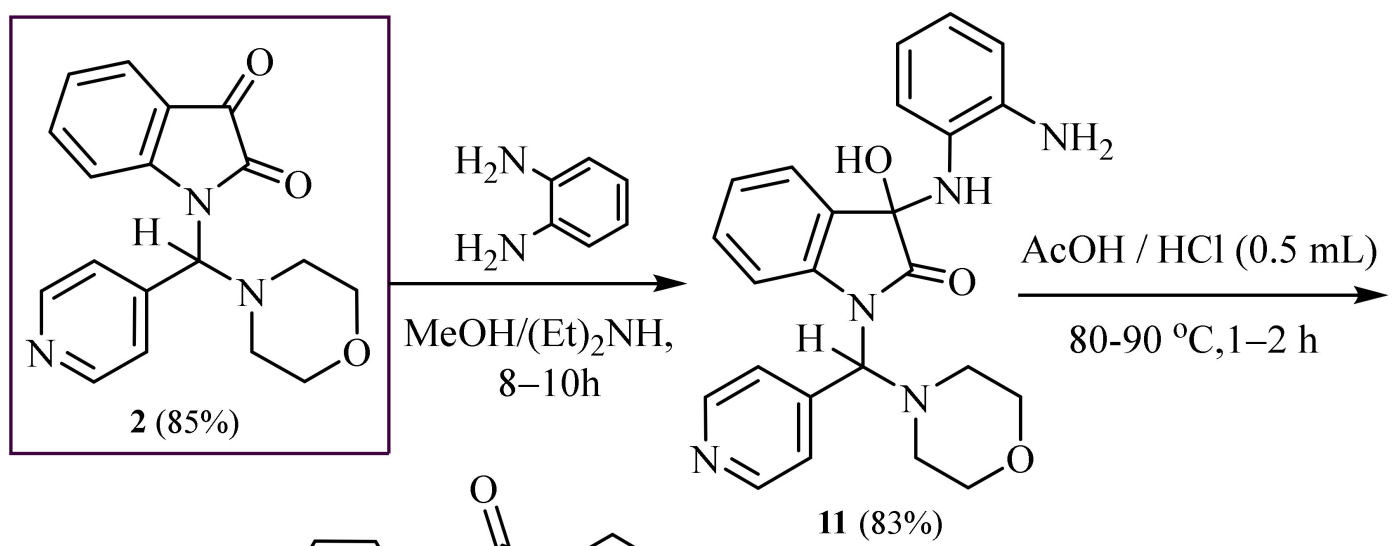<smiles>Nc1ccccc1NC1(O)C(=O)N(C(c2ccncc2)(c2ccncc2)N2CCOCC2)c2ccccc21</smiles><smiles>O=CN(C=O)c1ccccc1/N=C1/C(=O)N(C(c2ccncc2)N2CCOCC2)c2ccccc21</smiles>

$13(75 \%)$

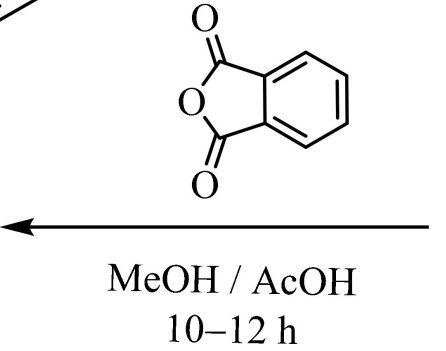

$10-12 \mathrm{~h}$<smiles>Nc1ccccc1N=C1C(=O)N(C(c2ccncc2)(c2ccncc2)N2CCOCC2)c2ccccc21</smiles>

$12(80 \%)$

Scheme 4. Synthesis of amino, imino,-phenyl and isoindoline-dione linked with indolinones.

Herein we describe the synthesis and design of a series of isatin derivatives, hydrazine1- carbothioamide; thioxospiro [indoline-3,3'-[1,2,4] triazolidin]-one; spiro [indoline-3,2' $[1,3,4]$ thiadiazol]-one and 3-((2-thioxo-imidazo [4,5-b] quinoxaline) imino) through reaction of thiosemicarbazide with isatin moieties.

Furthermore, the thiosemicarbazide with 1-(morpholino (pyridine) methyl) isatins (2) in glacial acetic acid was heated and refluxed to produce the target of 2- (1- (morpholino (pyridin-4-yl) methyl)-2-oxoindolin-3-ylidene) hydrazine-1- carbothioamide (14) as key starting material to synthesize many heterocyclic compounds. The IR spectrum of compound (14) exhibited absorption bands at $v 3430$ and $3320 \mathrm{~cm}^{-1}$ corresponding to $\mathrm{NH}_{2}$ and $\mathrm{NH}$ groups, $v 1678 \mathrm{~cm}^{-1}$ for one carbonyl group and $1475 \mathrm{~cm}^{-1}$ for one $(\mathrm{C}=\mathrm{S})$ group. ${ }^{1} \mathrm{H}-\mathrm{NMR}$ spectrum of (14) demonstrated one singlet at $\delta 6.61 \mathrm{ppm}$ corresponding to one proton of methine proton and two singlets at $\delta 6.90$ and $11.35 \mathrm{ppm}$ corresponding to the two protons of $\left(\mathrm{NH}_{2}\right)$ and one proton of $(\mathrm{NH})$ groups $\left(\mathrm{D}_{2} \mathrm{O}\right.$ exchangeable), respectively.

Additionally, a new one-pot multi-component reaction for the perfect selective synthesis of the various spiro-indolines-based frameworks has been described. Thus, the multicomponent reaction involves the compound isatin (2) and thiosemicarbazide in glacial 
acetic acid under reflux for a long time to form 1-(morpholino (pyridin-4-yl) methyl)-5'thioxospiro [indoline-3,3'-[1,2,4] triazolidin]-2-one (15).

Furthermore, the same compound (15) can be prepared in another way, which is to use cycloaddition reactions of the latter compound (14) in dry chloroform or glacial acetic acid with a few drops of triethylamine as catalysis for a long time under reflux and (TLC) control. The IR spectrum compound 15 showed absorption bands at $v 3350-3230 \mathrm{~cm}^{-1}$ compatible with three $(3 \mathrm{NH})$ groups and $v 1688 \mathrm{~cm}^{-1}$ conforming to one carbonyl group and $v 1450 \mathrm{~cm}^{-1}$ for one $(\mathrm{C}=\mathrm{S})$ group.

${ }^{1} \mathrm{H}-\mathrm{NMR}$ spectrum of 15 revealed three broad singlets at $\delta 10.10,10.40$ and $11.55 \mathrm{ppm}$ corresponding to three protons of $(3 \mathrm{NH})$ groups $\left(\mathrm{D}_{2} \mathrm{O}\right.$ exchangeable). The ${ }^{13} \mathrm{C}-\mathrm{NMR}$ spectrum of 15 showed absorption signals at $\delta 97.1 \mathrm{ppm}$ conforming to one spiro-carbon atom of (1C, $5^{\prime}$-thioxospiro[indoline-3,3'-[1,2,4] triazolidin]-2-one) and $\delta 168.2 \mathrm{ppm}$ for one carbon atom of the one carbonyl group.

In addition, $5^{\prime}$-amino-1-(morpholino (pyridin-4-yl) methyl)- $3^{\prime} H$-spiro[indoline-3, $2^{\prime}$ $[1,3,4]$ thiadiazol]-2-one (16) was prepared separately using compound (14) and iodine with potassium carbonate in boiling dioxane or DMF for long periods of time.

Another method for synthesizing a compound (16) is refluxing of compound (14) in ethanol containing a few drops of triethylamine as catalysis under (TLC) control. The IR spectrum of (16) displayed absorption bands at $v 3420$ and $3335 \mathrm{~cm}^{-1}$ matching $\mathrm{NH}_{2}$ and $\mathrm{NH}$ groups and $v 1682 \mathrm{~cm}^{-1}$ for one carbonyl group. ${ }^{1} \mathrm{H}-\mathrm{NMR}$ spectrum of (16) proved one singlet at $\delta 6.85 \mathrm{ppm}$ corresponding to two protons of $\left(\mathrm{NH}_{2}\right)$ and $10.25 \mathrm{ppm}$ corresponding to one proton of $(\mathrm{NH})$ groups exchangeable with $\mathrm{D}_{2} \mathrm{O}$. The ${ }^{13} \mathrm{C}-\mathrm{NMR}$ spectrum of (16) indicated absorption signals at $\delta 78.5 \mathrm{ppm}$ corresponding to one spiro-carbon atom of $(1 \mathrm{C}$, $3^{\prime} H$-spiro[indoline-3,2'-[1,3,4]thiadiazol]-2-one) and $\delta 167.5 \mathrm{ppm}$ for one carbon atom of the one carbonyl group.

Moreover, 1-(morpholino (pyridin-4-yl) methyl)-3-((2-thioxo-2,3-dihydro-1H-imidazo [4,5-b] quinoxalin-1-yl) imino) indolin-2-one (17) was synthesized by nucleophilic aromatic substitution reactions of compound (14) with 2,3-dichloro-quinoxaline by refluxing in absolute ethanol in the presence of triethylamine as catalysis. The IR spectrum of (17) exposed absorption bands at $v 3340 \mathrm{~cm}^{-1}$ corresponding to $\mathrm{NH}$ group, $1686 \mathrm{~cm}^{-1}$ compatible with one carbonyl group and $v 1480 \mathrm{~cm}^{-1}$ conforming to one $(\mathrm{C}=\mathrm{S})$ group. ${ }^{1} \mathrm{H}-\mathrm{NMR}$ spectrum of (17) revealed one singlet at $\delta 10.60 \mathrm{ppm}$ conforming to one proton of $(\mathrm{NH})$ group $\left(\mathrm{D}_{2} \mathrm{O}\right.$ exchangeable).

MS spectrum of $(\mathbf{1 4}, \mathbf{1 5}, \mathbf{1 6}$ and $\mathbf{1 7})$ displayed molecular ion peaks at $m / z=396\left(\mathrm{M}^{+}\right.$, $100 \%), 396\left(\mathrm{M}^{+}, 94 \%\right), 396\left(\mathrm{M}^{+}, 90 \%\right)$ and $522\left(\mathrm{M}^{+}, 97 \%\right)$, respectively. Correct new chemical structures were evidenced via spectroscopic, infrared, nuclear magnetic resonance, mass spectra and elemental analysis, shown in (Exp. Part and Scheme 5).

\subsection{Pharmacological Activities}

\subsubsection{Anticancer Screening}

In Vitro Cytotoxic Activity

The cytotoxic activities of new isatin derivatives were measured using the MTT colorimetric method by Mosmann (1983) [22-33,54] against four cancer cell lines: MGC-803 cells are drug-sensitive human gastric carcinoma cells; MCF-7 cells are drug-sensitive human breast adenocarcinoma cells; CNE2 cells are drug-sensitive human nasopharyngeal carcinoma cells; and KB cells are drug-sensitive human oral carcinoma cells.

The $\mathrm{IC}_{50}$ values are summarized in (Table 1 ) and compared to 5-Fluorouracil as a positive control. $\mathrm{IC}_{50}$ values are located over a wide range of concentrations, from $9 \mu \mathrm{M}$ to over $50 \mu \mathrm{M}$, showing a significant disparity in the cytotoxicity of the isatin compounds of various cancer cell lines.

The cytotoxic effects are cell-line-dependent, in the study of the final results shown in (Table 1) through the effect of isatin derivatives against the types of human carcinoma cell lines. Some of the compounds such as 17, 10, 9, 16 and 15 gave the highest anticancer 
activity; the same compounds 17, 10,9,16 and 15 represented the best effect of cytotoxicity and exceeded the drugs of 5-Fluorouracil positive control.

Moreover, the compounds 17, 10, 9, 16 and 15 have the best activities against all carcinoma cell lines in the following: the $\mathrm{IC}_{50}$ compounds 17, 10, 9, 16 and 15; the MGC$803(9.7,9.8,9.9,10.1,10.3 \mu \mathrm{M})$; the MCF-7 $(9.6,9.7,9.8,10.0,10.2 \mu \mathrm{M})$; the CNE2 (9.5, 9.6, 9.7, 9.9, $10.1 \mu \mathrm{M})$; and the KB $(9.4,9.5,9.6,9.8,9.9 \mu \mathrm{M})$. Furthermore, some of the compounds that moderate resulted in activities against cancer cells such as $7, \mathbf{1 3}, \mathbf{6}$ and 5 . Further, the rest of the compounds in this manuscript have a weak effect against cancer cells. All results concerning the compounds' anticancer activities in vitro are shown in (Table 1).

\subsubsection{Structural Activity Relationship (SAR)}

Isatin derivatives presented good antitumor activities against human cancer cell lines such as gastric, breast, nasopharyngeal, oral, lung and leukemia [22-33,55]. Furthermore, through the results we obtained, we can discuss the relationship of the chemical structures (SARs) of the synthesized compounds and their effect on the different types of cancer cell lines via the cytotoxicity activity of these compounds as follows:

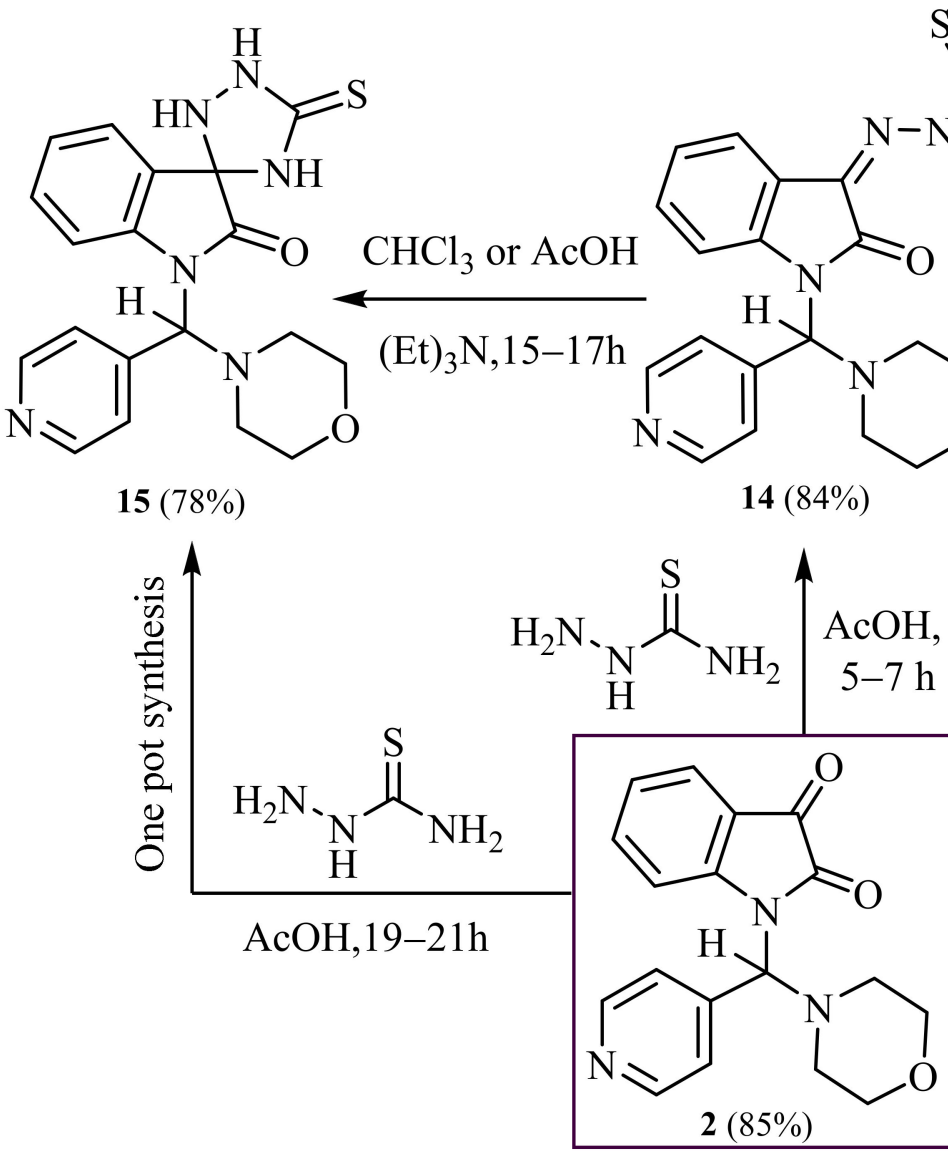<smiles>NC(N)=S</smiles>

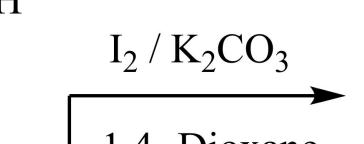<smiles>CC1(N2C(=O)C3(NN=C(N)S3)c3ccccc3C2(c2ccncc2)N2CCOCC2)CC1</smiles><smiles>Clc1nc2ccccc2nc1Cl</smiles>

EtOH / TEA, $22-25 h$ 13-15h<smiles>O=C1Nc2ccccc2/C1=N\n1c(N2CCOCCC2(c2ccncc2)c2ccncc2)nc2ccccc21</smiles>

$17(74 \%)$

Scheme 5. Synthesis of 1,2,4-triazole, 1,3,4-thiadiazole, -spiroindolinone and imidazo [4,5-b] quinoxaline-indolinones.

(I) these compounds 17, 10, 9, 16 and 15 (Table 2), exhibited excellent anticancer activity and some of the compounds $(7,13,6$ and 5) showed good anticancer activity in vitro. This agrees with previous scientific studies, because it includes many heterocyclic compounds possessing pharmacological activities such as imidazo[4,5-b]quinoxalineiminoindolinone, $\mathrm{N}$-thiazolo[3,2-a]pyrimidine-oxoindoline, $\mathrm{N}$-(pyrimidine)-oxoindolinehydrazine-1-carboxamide, spiro[indoline-3, 2'-[1,3,4] thiadiazol]-2-one, thioxospiro[indoline-3, $3^{\prime}-[1,2,4]$ triazolidin]-one, oxoindoline-benzo[4,5]thieno[2, 3-d]pyrimidinone, oxoin 
doline-amino-isoindolinone, oxoindoline-amino-benzo[b]thiophene-3-carboxylate and 1(morpholino (pyridine) methyl)-3-(thiazolo-imino) indolinone. They have proved potent anticancer activities [22-33,55].

Table 1. Cytotoxic activities of the new isatin derivatives against diverse human cancer cell lines.

\begin{tabular}{cccccc}
\hline \multirow{2}{*}{ Compounds } & \multicolumn{3}{c}{ In Vitro Cytotoxicity IC $_{\mathbf{5 0}}(\boldsymbol{\mu M}) \pm \mathbf{S D}$} & \multirow{2}{*}{ TI } \\
\cline { 2 - 5 } & MGC-803 ${ }^{\mathbf{a}}$ & MCF-7 $^{\mathbf{a}}$ & CNE2 $^{\mathbf{a}}$ & KB $^{\mathbf{a}}$ & \\
\hline $\mathbf{1}$ & $>50$ & $>50$ & $>50$ & $>50$ & 2.1 \\
$\mathbf{2}$ & $35.7 \pm 1.5$ & $35.4 \pm 1.2$ & $35.3 \pm 1.6$ & $35.2 \pm 1.4$ & 1.9 \\
$\mathbf{3}$ & $27.8 \pm 1.2$ & $27.6 \pm 1.4$ & $27.4 \pm 1.5$ & $27.1 \pm 1.2$ & 1.8 \\
$\mathbf{4}$ & $20.9 \pm 1.4$ & $20.7 \pm 1.5$ & $20.5 \pm 1.3$ & $20.2 \pm 1.1$ & 1.7 \\
$\mathbf{5}$ & $11.8 \pm 1.3$ & $11.6 \pm 1.4$ & $11.5 \pm 1.2$ & $11.3 \pm 1.3$ & 1.4 \\
$\mathbf{6}$ & $10.9 \pm 1.1$ & $10.8 \pm 1.3$ & $10.7 \pm 1.1$ & $10.5 \pm 1.5$ & 1.3 \\
$\mathbf{7}$ & $10.5 \pm 1.2$ & $10.4 \pm 1.1$ & $10.2 \pm 1.4$ & $10.1 \pm 1.2$ & 1.1 \\
$\mathbf{8}$ & $12.9 \pm 1.3$ & $12.8 \pm 1.5$ & $12.6 \pm 1.4$ & $12.5 \pm 1.6$ & 1.6 \\
$\mathbf{9}$ & $9.9 \pm 1.1$ & $9.8 \pm 1.2$ & $9.7 \pm 1.1$ & $9.6 \pm 1.2$ & 0.6 \\
$\mathbf{1 0}$ & $9.8 \pm 1.2$ & $9.7 \pm 1.1$ & $9.6 \pm 1.3$ & $9.5 \pm 1.1$ & 0.5 \\
$\mathbf{1 1}$ & $14.5 \pm 1.1$ & $14.3 \pm 1.3$ & $14.2 \pm 1.4$ & $14.1 \pm 1.2$ & 1.4 \\
$\mathbf{1 2}$ & $13.8 \pm 1.5$ & $13.7 \pm 1.2$ & $13.5 \pm 1.1$ & $13.3 \pm 1.4$ & 1.3 \\
$\mathbf{1 3}$ & $10.7 \pm 1.3$ & $10.6 \pm 1.5$ & $10.4 \pm 1.3$ & $10.2 \pm 1.1$ & 1.2 \\
$\mathbf{1 4}$ & $12.6 \pm 1.4$ & $12.4 \pm 1.6$ & $12.3 \pm 1.5$ & $12.1 \pm 1.2$ & 1.5 \\
$\mathbf{1 5}$ & $10.3 \pm 1.1$ & $10.2 \pm 1.2$ & $10.1 \pm 1.3$ & $9.9 \pm 1.4$ & 0.9 \\
$\mathbf{1 6}$ & $10.1 \pm 1.3$ & $10.0 \pm 1.4$ & $9.9 \pm 1.2$ & $9.8 \pm 1.3$ & 0.8 \\
$\mathbf{1 7}$ & $9.7 \pm 1.1$ & $9.6 \pm 1.2$ & $9.5 \pm 1.1$ & $9.4 \pm 1.2$ & 0.4 \\
\hline 5-Fluorouracil & $10.7 \pm 1.2$ & $10.5 \pm 1.1$ & $10.3 \pm 1.3$ & $10.1 \pm 1.1$ & 0.7
\end{tabular}

a MGC-803 cells are drug-sensitive human gastric carcinoma cells; MCF-7 cells are drug-sensitive human breast adenocarcinoma cells; CNE2 cells are drug-sensitive human nasopharyngeal carcinoma cells; and KB cells are drug-sensitive human oral carcinoma cells.

(II) These compounds $(17, \mathbf{1 0}, 9, \mathbf{1 6}, \mathbf{1 5}, \mathbf{7}, \mathbf{1 3}, \mathbf{6}$ and 5) produce the highest anticancer activity due to the presence of many functional groups linked heterocyclic moieties such as imidazole; quinoxaline; oxoindoline; thiazole, pyrimidine; hydrazine-1-carboxamide; spiroindolinone; 1,3,4- thiadiazole; thioxospiroindolinone; 1,2,4- triazolidinone; pyridine; morpholine; thiophene; amino, phenyl, ethyl, and methyl groups; isatin; imidazoquinoxaline; thiazolopyrimidine; benzothienopyrimidine; and heteroatoms such as nitrogen, oxygen and sulfur. Therefore, the presence of these groups leads to the electron withdrawing; lipophilic groups at different positions on the pyridine, morpholine, thiophene and phenyl rings; and hydrophobic reactions of the quinoxaline ring in the protein active site.

(III) Isatin derivatives are used for their anti-proliferative and antitumor properties and are considered are drugs. They deserve special attention, due to the following reasons:

- Isatin derivatives are used as free ligands or coordinated bonds with many metal and organic ions. Hence, they provide promising anti-proliferative properties against different cancer cells.

- Isatin-containing ligands have been fused with drug delivery systems for anti-tumor application.

- Isatin and its derivatives have the ability to bind to nucleic acid (DNA) and generate different types of ions that act as antioxidants and also inhibit selected proteins.

(IV) Isatin (1H-indol-2, 3-Dione) is extracted as a red-orange powder from plants of the Isatis genus (Isatis tinctoria) and is a natural compound of alkaloids. Furthermore, indolic compounds are natural compounds found in these plants that have wide-ranging biological activity as anti-inflammatory and anti-tumor.

- In addition, isatin has been detected in the human body as a metabolite of tryptophan or epinephrine, and it is widely distributed in the central nervous system (CNS) [55]. 
Table 2. The best new isatin derivatives with cytotoxic activity against different human cancer cell lines.

\begin{tabular}{|c|c|c|c|c|c|}
\hline \multirow{3}{*}{ Chemical Structures } & \multicolumn{4}{|c|}{ In vitro Cytotoxicity $\mathrm{IC}_{50}(\mu \mathrm{M}) \pm \mathrm{SD}$} & \multirow{3}{*}{ TI } \\
\hline & MGC-803 $^{a}$ & MCF-7 ${ }^{a}$ & $\mathrm{CNE}^{\mathrm{a}}$ & $\mathrm{KB}^{\mathbf{a}}$ & \\
\hline & \multicolumn{4}{|c|}{ Functional Groups/Heterocyclic Moieties } & \\
\hline & $9.7 \pm 1.1$ & $9.6 \pm 1.2$ & $9.5 \pm 1.1$ & $9.4 \pm 1.2$ & \multirow[b]{2}{*}{0.4} \\
\hline & \multicolumn{4}{|c|}{$\begin{array}{l}\text { Isatin, morpholine, pyridine, methyl, thioxo, imidazo [4,5-b] quinoxaline, } \\
\text { carbonyl group, nitrogen, oxygen and sulfur atoms. }\end{array}$} & \\
\hline & $9.8 \pm 1.2$ & $9.7 \pm 1.1$ & $9.6 \pm 1.3$ & $9.5 \pm 1.1$ & \\
\hline & \multicolumn{4}{|c|}{$\begin{array}{l}\text { Isatin, morpholine, pyridine, methyl, hydrazine, carboxamide, thiazolo } \\
\text { [3,2-a] pyrimidine, four carbonyl groups, nitrogen, oxygen and sulfur } \\
\text { atoms. }\end{array}$} & 0.5 \\
\hline & $9.9 \pm 1.1$ & $9.8 \pm 1.2$ & $9.7 \pm 1.1$ & $9.6 \pm 1.2$ & \\
\hline & \multicolumn{4}{|c|}{$\begin{array}{l}\text { Isatin, morpholine, pyridine, methyl, hydrazine, carboxamide, pyrimidine } \\
\text { ring, three carbonyl groups, nitrogen, oxygen and sulfur atoms. }\end{array}$} & 0.6 \\
\hline & $10.1 \pm 1.3$ & $10.0 \pm 1.4$ & $9.9 \pm 1.2$ & $9.8 \pm 1.3$ & \\
\hline & \multicolumn{4}{|c|}{$\begin{array}{l}\text { Isatin, morpholine, pyridine, methyl, amino, spiro } \\
\text { [indoline-1,3,4-thiadiazole], carbonyl group, nitrogen, oxygen and sulfur } \\
\text { atoms. }\end{array}$} & 0.8 \\
\hline & $10.3 \pm 1.1$ & $10.2 \pm 1.2$ & $10.1 \pm 1.3$ & $9.9 \pm 1.4$ & \\
\hline & \multicolumn{4}{|c|}{$\begin{array}{l}\text { Isatin, morpholine, pyridine, methyl, thioxo, spiro [indoline-1, 2, 4- } \\
\text { triazolidinone], carbonyl group, nitrogen, oxygen and sulfur atoms. }\end{array}$} & 0.9 \\
\hline
\end{tabular}


Table 2. Cont.

\begin{tabular}{|c|c|c|c|c|c|}
\hline \multirow{3}{*}{ Chemical Structures } & \multicolumn{4}{|c|}{ In vitro Cytotoxicity $\mathrm{IC}_{50}(\mu \mathrm{M}) \pm \mathrm{SD}$} & \multirow{3}{*}{ TI } \\
\hline & $\mathrm{MGC}-803^{\mathrm{a}}$ & MCF-7 ${ }^{a}$ & $\mathrm{CNE}^{\mathrm{a}}$ & $\mathrm{KB}^{\mathrm{a}}$ & \\
\hline & \multicolumn{4}{|c|}{ Functional Groups/Heterocyclic Moieties } & \\
\hline & $10.7 \pm 1.2$ & $10.5 \pm 1.1$ & $10.3 \pm 1.3$ & $10.1 \pm 1.1$ & \\
\hline $\mathrm{H}$ & \multicolumn{4}{|c|}{$\begin{array}{l}\text { Pyrimidine ring, two carbonyl groups, nitrogen, oxygen and fluorine } \\
\text { atoms. }\end{array}$} & 0.7 \\
\hline 5-Fluorouracil & & & & & \\
\hline
\end{tabular}

${ }^{\text {a }}$ MGC-803 cells are drug-sensitive human gastric carcinoma cells; MCF-7 cells are drug-sensitive human breast adenocarcinoma cells; CNE2 cells are drug-sensitive human nasopharyngeal carcinoma cells; and KB cells are drug-sensitive human oral carcinoma cells.

\section{Experimental Section}

Through cooperation with the teamwork of researchers, a research plan was made for the synthesis of new heterocyclic compounds. These new compounds were planned to study their biological activity as anticancer, and this plan was successfully implemented.

\subsection{General Information}

All melting points were taken on an Electrothermal IA 9100 series digital melting point apparatus (Shimadzu, Tokyo, Japan). Elemental analyses were performed on Vario EL (Elementar, Langenselbold, Germany). Microanalytical data were processed in the microanalytical center of the Faculty of Science at Cairo University and National Research Centre. The IR spectra (KBr disc) were recorded using a Perkin-Elmer 1650 spectrometer (Waltham, MA, USA). NMR spectra were determined using JEOL $270 \mathrm{MHz}$ and JEOL JMS-AX 500 MHz (JEOL, Tokyo, Japan) spectrometers with Me4Si as an internal standard. Mass spectra were recorded on an EI Ms-QP 1000 EX instrument (Shimadzu, Tokyo, Japan) at $70 \mathrm{eV}$. Biological evaluations were done by the anticancer unit of Mansoura University, Faculty of Pharmacy (Department of Pharmacognosy), 35516, Egypt. All starting materials and solvents were purchased from Sigma-Aldrich (Saint Louis, MO, USA).

\subsection{Synthesis of 1-(Morpholino (Pyridin-4-yl) Methyl) Indoline-2,3-Dione (2)}

General procedure for the preparation of Mannich bases [51-53].

To a warm solution of isatin $\mathbf{1}(1.47 \mathrm{~g}, 0.01 \mathrm{~mol})$ in sodium ethoxide solution $(40 \mathrm{~mL}$ of ethanol and $0.23 \mathrm{~g}, 0.01 \mathrm{~mol}$ of sodium metal) was added the freshly distilled secondary aliphatic amine, as morpholine $(0.87 \mathrm{~mL}, 0.01 \mathrm{~mol})$ and isonicotinaldehyde $(1.07 \mathrm{~g}, 0.01 \mathrm{~mol})$ were stirred under reflux in sodium ethoxide solution $(35 \mathrm{~mL})$ for 8-10 h (TLC control). The reaction mixture was cooled at room temperature, poured into cold water, acidified via conc. $\mathrm{HCl}$ and neutralized. The formed precipitate was filtered off, dried and recrystallized from dioxane, forming yellowish crystals $(85 \%)$, with m. p. $=283-285{ }^{\circ} \mathrm{C}$ (dec.). IR $\left(v, \mathrm{~cm}^{-1}\right) \mathrm{KBr}: 3055$ (CH, aryl), 2940 (CH, aliph), 1735 (CO, keton), 1680 (CO, amide); ${ }^{1} \mathrm{H}$ NMR (DMSO-d6, ppm) $\delta$ 2.60-3.05 (m, 8H, morpholine), 6.72 (s,1H, methine proton), 7.10-7.40 (m, 4H, phenyl), 7.50-7.60 (dd, 2H, $J=7.20 \mathrm{~Hz}$, pyridine), 7.70-7.80 (dd, 2H, $J=7.15 \mathrm{~Hz}$, pyridine); ${ }^{13} \mathrm{C}$ NMR $\left(\mathrm{DMSO}_{-} d_{6}\right) \delta 51.2,58.8\left(4 \mathrm{C}, 4 \mathrm{CH}_{2}\right.$, morpholine), 95.4 (1C, $\mathrm{CH}$, methine proton), 116.5, 117.1, 124.7, 127.2, 129.8, 135.3, 145.5, 148.6, 149.5 (11C, Ar-C), $161.2,172.8$ (2C, two carbonyl groups); MS (70 ev, \%): $m / z=323\left(\mathrm{M}^{+}, 100 \%\right)$; Anal. Calc. (Found) for $\mathrm{C}_{18} \mathrm{H}_{17} \mathrm{~N}_{3} \mathrm{O}_{3}$ (323.35): C, 66.86 (66.80); H, 5.30 (5.37); N, 13.00 (13.08).

\subsection{Synthesis of 3-((4-Bromophenyl) Imino)-1-(Morpholino (Pyridin-4-yl) Methyl) Indolin-2-One (3)}

A mixture of $2(3.23 \mathrm{~g}, 0.01 \mathrm{~mol})$ and 4-bromoaniline $(1.72 \mathrm{~g}, 0.01 \mathrm{~mol})$ in methanolic potassium hydroxide solution (prepared by dissolving $10 \mathrm{mmol}$ of $\mathrm{KOH}$ in $40 \mathrm{~mL}$ methanol) was refluxed for 10-12 h. The solid precipitate was obtained by filtering, washed with 
$100 \mathrm{~mL}$ of cold water and ethanol, dried and recrystallized from acetone, forming brownish crystals (80\%), with m. p. > $350{ }^{\circ} \mathrm{C}$ (dec.). IR $\left(v, \mathrm{~cm}^{-1}\right) \mathrm{KBr}: 3060(\mathrm{CH}$, aryl), $2935(\mathrm{CH}$, aliph), 1688 (CO, amide); ${ }^{1} \mathrm{H}$ NMR (DMSO-d6, ppm) $\delta$ 2.65-3.10 (m, 8H, morpholine), $6.70(\mathrm{~s}, 1 \mathrm{H}$, methine proton), 7.01-7.04 (dd, 2H, $J=7.02 \mathrm{~Hz}, 4$-bromophenyl), 7.14-7.40 (m, $4 \mathrm{H}$, phenyl), 7.55-7.65 (dd, 2H, J = 7.05 Hz, pyridine), $7.75-7.85$ (dd, 2H, J = 7.08 Hz, pyridine), $7.90-7.95$ (dd, $2 \mathrm{H}, J=7.04 \mathrm{~Hz}$, 4-bromophenyl); ${ }^{13} \mathrm{C}$ NMR (DMSO- $\left.d_{6}\right) \delta 51.5$, 58.9 (4C, $4 \mathrm{CH}_{2}$, morpholine), 94.7 (1C, $\mathrm{CH}$, methine proton), 116.1, 117.5, 120.8, 122.3, 124.5, 124.8, 129.1, 130.4, 132.5, 145.8, 147.7, 149.2, 151.6, 160.9 (18C, Ar-C), 164.1 (1C, carbonyl groups); MS (70 ev, \%): $m / z=477\left(\mathrm{M}^{+}, 100 \%\right)$; Anal. Calc. (Found) for $\mathrm{C}_{24} \mathrm{H}_{21} \mathrm{BrN}_{4} \mathrm{O}_{2}$ (477.36): C, 60.39 (60.30); H, 4.43 (4.50); N, 11.74 (11.66).

\subsection{Synthesis of 2-((1-(Morpholino (Pyridin-4-yl) Methyl)-2-Oxoindolin-3-Ylidene) Amino) Benzoic Acid (4)}

A mixture of 2 (3.23 g, $0.01 \mathrm{~mol})$ and 2-aminobenzoic acid $(1.37 \mathrm{~g}, 0.01 \mathrm{~mol})$ in dimethylformamide $(45 \mathrm{~mL})$ in the presence of anhydrous potassium carbonate $(0.015 \mathrm{~mol})$ was refluxed for 7-9 $\mathrm{h}$ with (TLC). The reaction mixture was stirred at room temperature for two hours and poured into cold water with neutralized. The solid precipitate formed was filtered off, dried and crystallized from methanol in (84\%) yield, forming yellow crystals, with m. p. $=345-347^{\circ} \mathrm{C}$ (dec.). IR $\left(v, \mathrm{~cm}^{-1}\right) \mathrm{KBr}: 3750$ (br., OH), $3070(\mathrm{CH}$, aryl), 2948 (CH, aliph), 1740 (CO, acid), 1688 (CO, amide), $1630(\mathrm{C}=\mathrm{N})$ and $1590(\mathrm{C}=\mathrm{C})$; ${ }^{1} \mathrm{H}$ NMR (DMSO-d6, ppm) $\delta$ 2.70-3.15 (m, 8H, morpholine), 6.75 (s,1H, methine proton), 7.35-7.45 (dd, 2H, J = 7.01 Hz, pyridine), 7.50-7.88 (m, 8H, phenyl), 7.90-7.99 (dd, 2H, $J=7.03 \mathrm{~Hz}$, pyridine), 12.60 (br., $1 \mathrm{H}, \mathrm{OH}, \mathrm{D}_{2} \mathrm{O}$ exchangeable); ${ }^{13} \mathrm{C}$ NMR (DMSO- $\left.d_{6}\right) \delta 52.2$, 59.1 (4C, $4 \mathrm{CH}_{2}$, morpholine), 95.3 (1C, $\mathrm{CH}$, methine proton), 116.5, 116.8, 117.9, 122.1, 122.7, $124.4,125.6,128.5,129.3,130.7,133.3,146.1,147.2,149.6,152.1,161.3$ (18C, Ar-C), 164.7, 167.1 (2C, two carbonyl groups); MS (70 ev, \%): $m / z=442\left(\mathrm{M}^{+}, 100 \%\right)$; Anal. Calc. (Found) for $\mathrm{C}_{25} \mathrm{H}_{22} \mathrm{~N}_{4} \mathrm{O}_{4}$ (442.47): C, 67.86 (67.80); $\mathrm{H}, 5.01$ (5.08); N, 12.66 (12.73).

\subsection{Synthesis of 1-(Morpholino (Pyridin-4-yl) Methyl) -3-(Thiazol-2-Ylimino) Indolin-2-One (5)}

A solution of $2(3.23 \mathrm{~g}, 0.01 \mathrm{~mol}), 2$-aminothiazole $(1.00 \mathrm{~g}, 0.01 \mathrm{~mol})$ and anhydrous potassium carbonate $(1.4 \mathrm{~g}, 0.01 \mathrm{~mol})$ in dry dimethylformamide $(40 \mathrm{~mL})$ was used as a solvent. The reaction mixture was heated and refluxed for 9-11 h under control (TLC), and then allowed to cool and poured into cold water. The final precipitate was filtered and recrystallized from dioxane in $(82 \%)$ yield, forming yellowish crystals, with m. p. $=333-335{ }^{\circ} \mathrm{C}$ (dec.). IR $\left(v, \mathrm{~cm}^{-1}\right) \mathrm{KBr}: 3061(\mathrm{CH}$, aryl $), 2957$ (CH, aliph), $1678(\mathrm{CO}$, amide $)$ and $1632(\mathrm{C}=\mathrm{N})$, $1585(\mathrm{C}=\mathrm{C}) .{ }^{1} \mathrm{H}$ NMR (DMSO-d6, ppm) $\delta$ 2.72-3.18 (m, 8H, morpholine), 6.67 (s,1H, methine proton), 7.30-7.40 (dd, $2 \mathrm{H}, J=7.01 \mathrm{~Hz}$, pyridine), 7.44-7.72 $(\mathrm{m}, 4 \mathrm{H}$, phenyl), 7.75-7.80 $(\mathrm{d}, 1 \mathrm{H}$, $J=6.90 \mathrm{~Hz}$, thiazole), $7.82-7.87(\mathrm{~d}, 1 \mathrm{H}, J=6.92 \mathrm{~Hz}$, thiazole), $7.89-7.98(\mathrm{dd}, 2 \mathrm{H}, J=7.03 \mathrm{~Hz}$, pyridine); ${ }^{13} \mathrm{C}$ NMR (DMSO- $\left.d_{6}\right) \delta 52.5,59.7\left(4 \mathrm{C}, 4 \mathrm{CH}_{2}\right.$, morpholine), 94.4 (1C, CH, methine proton), 116.4, 117.2, 117.6, 123.5, 124.1, 129.7, 130.5, 141.1, 146.3, 147.6, 149.3, 161.5, 165.9 (15C, Ar-C), 168.2 (1C, carbonyl groups); MS (70 ev, \%): m/z=405 (M+100\%); Anal. Calc. (Found) for $\mathrm{C}_{21} \mathrm{H}_{19} \mathrm{~N}_{5} \mathrm{O}_{2} \mathrm{~S}$ (405.48): C, 62.21 (62.30); H, 4.72 (4.80); N, 17.27 (17.18).

3.6. Synthesis of Ethyl-2-((1-(Morpholino (Pyridin-4-yl) Methyl)-2-Oxoindolin-3-Ylidene) amino)-4,5,6,7-Tetrahydrobenzo[b]thiophene-3-Carboxylate (6)

To a solution of compound 2 (3.23 g, $0.01 \mathrm{~mol})$, ethyl 2-amino-4,5,6,7-tetrahy- drobenzo [b]thiophene-3-carboxylate $(2.25 \mathrm{~g}, 0.01 \mathrm{~mol})$ and anhydrous potassium carbonate $(1.4 \mathrm{~g}$, $0.01 \mathrm{~mol})$ were added in dry dimethylformamide $(40 \mathrm{~mL})$, and the reaction mixture was refluxed for 10-12 h with control by (TLC). After cooling at room temperature, the reaction solution was poured onto ice water. The product precipitate was filtered off, dried and recrystallized from toluene in $(81 \%)$ yield, forming yellow crystals, with $\mathrm{m} . \mathrm{p} .>350{ }^{\circ} \mathrm{C}$ (dec.). IR $\left(v, \mathrm{~cm}^{-1}\right) \mathrm{KBr}: 3070$ (CH, aryl), 2960 (CH, aliph), 1775 (CO, ester), 1682 (CO, amide) and $1631(\mathrm{C}=\mathrm{N}), 1590(\mathrm{C}=\mathrm{C}) ;{ }^{1} \mathrm{HNMR}$ (DMSO- $\left.d_{6}, \mathrm{ppm}\right) \delta$ 1.08-1.15 (m,8H,cyclohexane), 1.28-1.35 (t, 3H, J =7.20 Hz, $\left.\mathrm{CH}_{3}\right), 2.75-3.22$ (m, 8H, morpholine), 4.42-4.49 (q, 2H, J = 7.22 Hz, $\left.\mathrm{CH}_{2}\right), 6.62$ (s,1H, methine proton), 7.25-7.33 (dd, 2H, J = 7.09 Hz, pyridine), 7.55-7.82 (m, 
$4 \mathrm{H}$, phenyl), 7.90-7.95 (dd, 2H, $J=7.08 \mathrm{~Hz}$, pyridine); ${ }^{13} \mathrm{C}$ NMR (DMSO- $\left.d_{6}\right) \delta 18.8(1 \mathrm{C}$, $\left.\mathrm{CH}_{3}\right), 21.5,22.4,23.1,24.7\left(4 \mathrm{C}, 4 \mathrm{CH}_{2}\right.$, cyclohexane), 52.8, $58.9\left(4 \mathrm{C}, 4 \mathrm{CH}_{2}\right.$, morpholine), $61.2\left(1 \mathrm{C}, \mathrm{CH}_{2}\right), 94.7(1 \mathrm{C}, \mathrm{CH}$, methine proton), 116.3, 117.9, 123.7, 124.5, 127.1, 128.8, 129.5, 130.9, 138.6, 146.1, 147.7, 149.5, 151.3, 160.8 (16C, Ar-C), 164.2, 166.9 (2C, carbonyl groups); MS (70 ev, \%): $m / z=530\left(\mathrm{M}^{+}, 100 \%\right)$; Anal. Calc. (Found) for $\mathrm{C}_{29} \mathrm{H}_{30} \mathrm{~N}_{4} \mathrm{O}_{4} \mathrm{~S}(530.64)$ : C, 65.64 (65.71); H, 5.70 (5.62); N, 10.56 (10.50).

3.7. Synthesis of 1-(1-(Morpholino(Pyridin-4-yl)Methyl)-2-Oxoindolin-3-yl)-5,6,7,8-Tetrahydro benzo[4,5]thieno[2,3-d]pyrimidin-4(1H)-One (7)

A mix of compound $6(5.30 \mathrm{~g}, 0.01 \mathrm{~mol})$ and formamide $(0.5 \mathrm{~mL}, 0.01 \mathrm{~mol})$ was stirred under reflux in dimethylformamide $(35 \mathrm{~mL})$ in the presence of anhydrous potassium carbonate $(0.015 \mathrm{~mol})$ for $16-18 \mathrm{~h}$ under control (TLC). The reaction solution was cooled at room temperature, poured into cold water and neutralized. The solid product formed was filtered off, dried and crystallized from dioxane in $(80 \%)$ yield, forming yellowish crystals, with m. p. $>350^{\circ} \mathrm{C}$ (dec.). IR $\left(v, \mathrm{~cm}^{-1}\right) \mathrm{KBr}$ : $3075(\mathrm{CH}$, aryl), $2970(\mathrm{CH}$, aliph), 1690, 1685 (2CO, amide) and $1634(\mathrm{C}=\mathrm{N}), 1588(\mathrm{C}=\mathrm{C}) ;{ }^{1} \mathrm{HNMR}$ (DMSO- $d_{6}, \mathrm{ppm}$ ) $\delta$ 110-1.18 (m,8H,cyclohexane), 2.80-3.27 ( $\mathrm{m}, 8 \mathrm{H}$, morpholine), 5.10 (s,1H, $\mathrm{CH}$, pyrrole), $6.58(\mathrm{~s}, 1 \mathrm{H}$, methine proton), 7.35-7.44 $(\mathrm{dd}, 2 \mathrm{H}, J=7.04 \mathrm{~Hz}$, pyridine $), 7.59-7.88(\mathrm{~m}, 4 \mathrm{H}$, phenyl), $7.92-7.97\left(\mathrm{dd}, 2 \mathrm{H}, J=7.05 \mathrm{~Hz}\right.$, pyridine), $8.15\left(\mathrm{~s}, 1 \mathrm{H}, \mathrm{CH}\right.$, pyrimidine); ${ }^{13} \mathrm{C}$ NMR (DMSO- $\left.d_{6}\right) \delta 21.7,22.8,23.4,24.9\left(4 \mathrm{C}, 4 \mathrm{CH}_{2}\right.$, cyclohexane), 52.9, $59.1\left(4 \mathrm{C}, 4 \mathrm{CH}_{2}\right.$, morpholine), 77.4 (1C, $\mathrm{CH}$, pyrrole), 93.9 (1C, $\mathrm{CH}$, methine proton), 117.7, 124.1, 124.6, 125.8, 127.5, 127.9, 129.7, 135.8, 138.8, 139.6, 144.5, 146.3, 148.2, 149.7, (16C, Ar-C), 163.8, 167.1 (2C, carbonyl groups); $\mathrm{MS}(70 \mathrm{ev}, \%): m / z=513\left(\mathrm{M}^{+}, 95 \%\right)$; Anal. Calc. (Found) for $\mathrm{C}_{28} \mathrm{H}_{27} \mathrm{~N}_{5} \mathrm{O}_{3} \mathrm{~S}$ (513.62): C, 65.48 (65.40); H, 5.30 (5.37); N, 13.64 (13.57).

\subsection{Synthesis of Ethyl-2-(1-(Morpholino (Pyridin-4-yl) Methyl)-2-Oxoindolin-3-Ylidene) Hydrazine-1-Carboxylate (8)}

A mix of compound 2 ( $3.23 \mathrm{~g}, 0.01 \mathrm{~mol})$, ethyl hydrazinecarboxylate $(1.04 \mathrm{~g}, 0.01 \mathrm{~mol})$ and anhydrous potassium carbonate $(1.4 \mathrm{~g}, 0.01 \mathrm{~mol})$ was formed in dry dimethylformamide $(45 \mathrm{~mL})$. The reaction mixture was heated under reflux for 11-13 $\mathrm{h}$ under control (TLC) and then allowed to cool and poured into cold water. The precipitate was filtered off, dried and recrystallized from n-hexane in (84\%) yield, yellowish crystals, $\mathrm{m} . \mathrm{p}=308-310^{\circ} \mathrm{C}$ (dec.). IR $\left(v, \mathrm{~cm}^{-1}\right) \mathrm{KBr}: 3325$ (br., NH), 3055 (CH, aryl), 2960 (CH, aliph), 1691, 1684 (2CO, amide), $1628(\mathrm{C}=\mathrm{N})$ and $1582(\mathrm{C}=\mathrm{C}) ;{ }^{1} \mathrm{HNMR}$ (DMSO- $\left.d 6, \mathrm{ppm}\right) \delta 1.29-1.36(\mathrm{t}, 3 \mathrm{H}, J=7.12 \mathrm{~Hz}$, $\left.\mathrm{CH}_{3}\right), 2.72-3.19\left(\mathrm{~m}, 8 \mathrm{H}\right.$, morpholine), 4.35-4.42 (q, $\left.2 \mathrm{H}, \mathrm{J}=7.10 \mathrm{~Hz}, \mathrm{CH}_{2}\right), 6.55(\mathrm{~s}, 1 \mathrm{H}$, methine proton), 7.32-7.41 (dd, $2 \mathrm{H}, J=7.01 \mathrm{~Hz}$, pyridine), 7.52-7.81 (m, 4H, phenyl), 7.88-7.95 (dd, $2 \mathrm{H}, J=7.02 \mathrm{~Hz}$, pyridine), 10.50 (br., $1 \mathrm{H}, \mathrm{NH}, \mathrm{D}_{2} \mathrm{O}$ exchangeable); ${ }^{13} \mathrm{C}$ NMR (DMSO- $d_{6}$ ) $\delta 19.1\left(1 \mathrm{C}, \mathrm{CH}_{3}\right), 52.6,58.5\left(4 \mathrm{C}, 4 \mathrm{CH}_{2}\right.$, morpholine), $61.7\left(1 \mathrm{C}, \mathrm{CH}_{2}\right), 93.5(1 \mathrm{C}, \mathrm{CH}$, methine proton), 116.1, 117.5, 124.1, 124.6, 129.2, 131.8, 132.7, 146.3, 147.5, 149.6 (12C, Ar-C), 161.1, 164.3 (2C, carbonyl groups); MS (70 ev, \%): $m / z=409\left(\mathrm{M}^{+}, 100 \%\right)$; Anal. Calc. (Found) for $\mathrm{C}_{21} \mathrm{H}_{23} \mathrm{~N}_{5} \mathrm{O}_{4}$ (409.45): C, 61.60 (61.67); $\mathrm{H}, 5.66$ (5.60); $\mathrm{N}, 17.10$ (17.17).

3.9. Synthesis of N-(2-Mercapto-6-oxo-1,6-Dihydropyrimidin-4-yl)-2-(1-(Morpholino (Pyridin-4yl) methyl)-2-Oxoindolin-3-Ylidene) Hydrazine-1-Carboxamide (9)

A suspension of compound $4(4.09 \mathrm{~g}, 0.01 \mathrm{~mol})$ and 6-amino-2-mercaptopyrimidin$4(3 \mathrm{H})$-one $(1.43 \mathrm{~g}, 0.01 \mathrm{~mol})$ in dry dimethylformamide $(40 \mathrm{~mL})$ containing a catalytic amount of TEA $(0.5 \mathrm{~mL})$ was stirred and heated under reflux for 13-15 h with (TLC) control. The reaction solution was cooled; the solid precipitate was filtered off, dried and recrystallized from methanol/ DMF in $(78 \%)$ yield, forming brownish crystals, with m. p. $>350^{\circ} \mathrm{C}$ (dec.). IR $\left(v, \mathrm{~cm}^{-1}\right) \mathrm{KBr}$ : 3330-3270 (br., 3NH), $3060(\mathrm{CH}$, aryl), $2970(\mathrm{CH}$, aliph), 1695, 1688, 1682 (3CO, amide), $1631(\mathrm{C}=\mathrm{N})$ and $1585(\mathrm{C}=\mathrm{C}) ;{ }^{1} \mathrm{HNMR}$ (DMSO-d6, ppm) $\delta 2.66(\mathrm{~s}, 1 \mathrm{H}, \mathrm{SH}), 2.75-3.25(\mathrm{~m}, 8 \mathrm{H}$, morpholine), $6.50(\mathrm{~s}, 1 \mathrm{H}$, methine proton), $6.85(\mathrm{~s}$, $1 \mathrm{H}, \mathrm{CH}$, pyrimidine), 7.36-7.42 (dd, $2 \mathrm{H}, J=7.06 \mathrm{~Hz}$, pyridine), $7.50-7.80(\mathrm{~m}, 4 \mathrm{H}$, phenyl), 7.85-7.92 (dd, $2 \mathrm{H}, J=7.04 \mathrm{~Hz}$, pyridine), 9.90 (br., $1 \mathrm{H}, \mathrm{NH}, \mathrm{D}_{2} \mathrm{O}$ exchangeable), 10.80 (br., $1 \mathrm{H}, \mathrm{NH}, \mathrm{D}_{2} \mathrm{O}$ exchangeable), 11.70 (br., $1 \mathrm{H}, \mathrm{NH}, \mathrm{D}_{2} \mathrm{O}$ exchangeable); ${ }^{13} \mathrm{C}$ NMR (DMSO- $d_{6}$ ) 
$\delta 51.9,58.7$ (4C, 4CH $\mathrm{CH}_{2}$ morpholine), 81.5 (1C, $\mathrm{CH}$, pyrimidine), 94.2 (1C, $\mathrm{CH}$, methine proton), 116.3, 117.6, 124.4, 124.8, 129.6, 131.5, 132.1, 146.7, 147.8, 149.7, 153.1, 160.2 (14C, Ar-C), 161.5, 164.1, 166.2 (3C, three carbonyl groups); MS (70 ev, \%): $m / z=409\left(\mathrm{M}^{+}, 100 \%\right)$; Anal. Calc. (Found) for $\mathrm{C}_{23} \mathrm{H}_{22} \mathrm{~N}_{8} \mathrm{O}_{4} \mathrm{~S}$ (506.54): C, 54.54 (54.62); H, 4.38 (4.31); N, 22.12 (22.07).

3.10. Synthesis of N-(3,5-Dioxo-2,3-Dihydro-5H-Thiazolo [3,2-a] Pyrimidin-7-yl)-2-(1- (Morpholino (Pyridin-4-yl) Methyl)-2-Oxoindolin-3-Ylidene) Hydrazine-1-Carboxamide (10)

Method A: A mixture of compound 9 (5.06 g, $0.01 \mathrm{~mol})$, chloroacetic acid (0.94 g, $0.01 \mathrm{~mol})$, and $0.02 \mathrm{~mol}$ of anhydrous sodium acetate was stirred under reflux in $(40 \mathrm{~mL}) \mathrm{of}$ glacial acetic acid and $(25 \mathrm{~mL})$ of acetic anhydride in a water bath $\left(85-95^{\circ} \mathrm{C}\right)$ for $17-19 \mathrm{~h}$ under control (TLC). The reaction mixture was cooled at room temperature and poured into cold water $(100 \mathrm{~mL})$. The solid precipitate was filtered off, dried and crystallized from a suitable solvent to yield (10). Method B: A solution of 9 (5.06 g, $0.01 \mathrm{~mol}$ ) and chloroacetic acid $(0.94 \mathrm{~g}, 0.01 \mathrm{~mol})$ in dimethylformamide $(35 \mathrm{~mL})$ was heated and refluxed for $14-16 \mathrm{~h}$ under control (TLC). The final precipitate was filtered off, dried and crystallized from $\mathrm{DMF} /$ methanol in good yields (75\%), forming yellowish crystals, with m. p. $>350{ }^{\circ} \mathrm{C}$ (dec.). IR $\left(v, \mathrm{~cm}^{-1}\right) \mathrm{KBr}: 3325-3280$ (br., 2NH), 3055 (CH, aryl), 2965(CH, aliph), 1691, 1686, 1681, 1675 (4CO, amide), $1634(\mathrm{C}=\mathrm{N})$ and $1582(\mathrm{C}=\mathrm{C}) ;{ }^{1} \mathrm{HNMR}$ (DMSO-d6, ppm) $\delta$ 2.78-3.28 (m, 8H, morpholine), $4.22\left(\mathrm{~s}, 2 \mathrm{H}, \mathrm{CH}_{2}\right.$, thiazole), 6.58 (s,1H, methine proton), 6.88 (s, 1H, CH, pyrimidine), 7.39-7.45 (dd, 2H, $J=7.08 \mathrm{~Hz}$, pyridine), 7.58-7.87 (m, 4H, phenyl), 7.91-7.98 (dd, 2H, $J=7.07 \mathrm{~Hz}$, pyridine),10.10 (br., $1 \mathrm{H}, \mathrm{NH}, \mathrm{D}_{2} \mathrm{O}$ exchangeable), 11.60 (br., $1 \mathrm{H}, \mathrm{NH}, \mathrm{D}_{2} \mathrm{O}$ exchangeable); ${ }^{13} \mathrm{C} \mathrm{NMR}\left(\mathrm{DMSO}-\mathrm{d}_{6}\right) \delta 32.1$ (1C, $\mathrm{CH}_{2}$, thiazole), 52.3, 59.1 (4C, $4 \mathrm{CH}_{2}$, morpholine), 82.3 (1C, $\mathrm{CH}$, pyrimidine), 93.5 (1C, $\mathrm{CH}$, methine proton), $116.1,117.9,124.5,124.7,129.5,131.4,132.5,146.2,147.6,149.5,153.3,159.1$ (14C, Ar-C), 161.8, 163.5, 165.7, 169.1 (4C, four carbonyl groups); MS (70 ev, \%): $m / z=546\left(\mathrm{M}^{+}, 92 \%\right)$; Anal. Calc. (Found) for $\mathrm{C}_{25} \mathrm{H}_{22} \mathrm{~N}_{8} \mathrm{O}_{5} \mathrm{~S}$ (546.56): C, 54.94 (54.86); H, 4.06 (4.01); N, 20.50 (20.59).

\subsection{Synthesis of 3-((2-Aminophenyl) Amino)-3-Hydroxy-1-(Morpholino (Pyridin-4-yl) Methyl) Indolin-2-One (11)}

To a mixture of 2 (3.23 g, $0.01 \mathrm{~mol})$, benzene-1,2-diamine $(1.08 \mathrm{~g}, 0.01 \mathrm{~mol})$ in absolute methanol $(30 \mathrm{~mL})$ and diethylamine $(0.73 \mathrm{~mL}, 0.01 \mathrm{~mol})$ was added. The reaction solution was stirred and refluxed at room temperature for $\sim 8-10 \mathrm{~h}$ and monitored by using TLC. The solid formed was filtered off, washed with water, dried and recrystallized from DMF in good yields (83\%), forming yellow crystals, with m. p. $=297-300{ }^{\circ} \mathrm{C}$ (dec.). IR $\left(v, \mathrm{~cm}^{-1}\right)$ KBr: 3415 (br., $\mathrm{NH}_{2}$ ), 3370-3330 (brs., OH, NH), 3060 (CH, aryl), 2950 (CH, aliph), 1682 (CO, amide), $1630(\mathrm{C}=\mathrm{N})$ and $1580(\mathrm{C}=\mathrm{C}) ;{ }^{1} \mathrm{H}$ NMR (DMSO-d6, ppm) $\delta$ 2.70-3.10 (m, 8H, morpholine), 6.25 (br., $2 \mathrm{H}, \mathrm{NH}_{2}, \mathrm{D}_{2} \mathrm{O}$ exchangeable), 6.60 (s,1H, methine proton), $7.22-7.30$ ( $\mathrm{dd}, 2 \mathrm{H}$, $J=7.09 \mathrm{~Hz}$, pyridine), 7.35-7.80 (m, 8H, phenyl), 7.85-7.97(dd, 2H, $J=7.07 \mathrm{~Hz}$, pyridine), 11.10 (br., $1 \mathrm{H}, \mathrm{NH}, \mathrm{D}_{2} \mathrm{O}$ exchangeable), 12.60 (br., $1 \mathrm{H}, \mathrm{OH}, \mathrm{D}_{2} \mathrm{O}$ exchangeable); ${ }^{13} \mathrm{C}$ NMR $\left(\mathrm{DMSO}-d_{6}\right) \delta 51.6,58.5$ (4C, $4 \mathrm{CH}_{2}$, morpholine), 93.1 (1C, $\mathrm{CH}$, methine proton), 111.4, 112.1, $114.8,116.9$, 118.2, 120.3, 124.4, 128.1, 128.9, 133.3, 135.2, 135.7, 137.5, 145.2, 147.4, 149.7 (18C, Ar-C), 165.7 (1C, carbonyl group); MS (70 ev, \%): $m / z=431\left(\mathrm{M}^{+}, 90 \%\right)$; Anal. Calc. (Found) for $\mathrm{C}_{24} \mathrm{H}_{25} \mathrm{~N}_{5} \mathrm{O}_{3}$ (431.50): C, 66.81 (66.73); $\mathrm{H}, 5.84$ (5.75); N, 16.23 (16.32).

\subsection{Synthesis of 3-((2-Aminophenyl) Imino)-1-(Morpholino (Pyridin-4-yl) Methyl) Indolin-2-one (12)}

A solution of compound $11(4.31 \mathrm{~g}, 0.01 \mathrm{~mol})$ in glacial acetic acid $(30 \mathrm{~mL})$ and concentrated $\mathrm{HCl}(0.5 \mathrm{~mL})$ was heated and refluxed at $80-90{ }^{\circ} \mathrm{C}$ for $\sim 1-2 \mathrm{~h}$. After cooling, the reaction mixture was cooled and poured into ice water. The solid precipitate that formed was filtered off, washed with water, air-dried and crystallized from dioxane in good yields $(80 \%)$, forming yellowish crystals, with m. p. $=320-322{ }^{\circ} \mathrm{C}(\mathrm{dec}.) . \mathrm{IR}\left(\nu, \mathrm{cm}^{-1}\right)$ KBr: 3410 (br., $\left.\mathrm{NH}_{2}\right), 3057$ (CH, aryl), 2953 (CH, aliph), 1684 (CO, amide), $1637(\mathrm{C}=\mathrm{N})$ and $1583(\mathrm{C}=\mathrm{C}) ;{ }^{1} \mathrm{H}$ NMR (DMSO-d6, ppm) $\delta$ 2.77-3.16 (m, 8H, morpholine), 6.35 (br., 2H, $\mathrm{NH}_{2}$, $\mathrm{D}_{2} \mathrm{O}$ exchangeable), 6.65 (s,1H, methine proton), 7.28-7.37 (dd, $2 \mathrm{H}, J=7.10 \mathrm{~Hz}$, pyridine), 7.40-7.85 (m, 8H, phenyl), 7.87-7.99 (dd, $2 \mathrm{H}, J=7.12 \mathrm{~Hz}$, pyridine); ${ }^{3} \mathrm{C}$ NMR (DMSO- $\left.d_{6}\right) \delta$ 51.8, 58.7 (4C, $4 \mathrm{CH}_{2}$, morpholine), 93.5 (1C, $\mathrm{CH}$, methine proton), 115.9, 117.4, 117.8, 123.7, 
124.1, 124.6, 127.2, 128.4, 129.6, 132.3, 140.8, 142.5, 146.3, 147.1, 149.5, 161.7 (18C, Ar-C), 165.9 (1C, carbonyl group); MS (70 ev, \%): $m / z=413\left(\mathrm{M}^{+}, 100 \%\right)$; Anal. Calc. (Found) for $\mathrm{C}_{24} \mathrm{H}_{23} \mathrm{~N}_{5} \mathrm{O}_{2}$ (413.48): C, 69.72 (69.80); $\mathrm{H}, 5.61$ (5.55); $\mathrm{N}, 16.94$ (16.88).

\subsection{Synthesis of 2-(2-((1-(Morpholino (Pyridin-4-yl) Methyl)-2-Oxoindolin-3-Ylidene) Amino)} phenyl) Isoindoline-1,3-Dione (13)

A solution of compound $12(4.13 \mathrm{~g}, 0.01 \mathrm{~mol})$ and phthalic anhydride $(1.48 \mathrm{~g}, 0.01 \mathrm{~mol})$ in absolute methanol ( $45 \mathrm{~mL})$ containing a few drops of glacial acetic acid was stirred and heated under reflux for $\sim 10-12 \mathrm{~h}$ with (TLC control). The solid precipitate obtained was filtered, dried and recrystallized from DMF in good yields (75\%), forming white crystals, with m. p. > $350{ }^{\circ} \mathrm{C}$ (dec.). IR ( $\left.v, \mathrm{~cm}^{-1}\right) \mathrm{KBr}: 3062$ (CH, aryl), 2958(CH, aliph), 1688, 1682, 1677 (3CO, amide), 1633(C=N) and $1585(\mathrm{C}=\mathrm{C}) ;{ }^{1} \mathrm{H}$ NMR (DMSO-d6, ppm) $\delta 2.80-3.20(\mathrm{~m}$, $8 \mathrm{H}$, morpholine), 6.60 (s,1H, methine proton), 7.13-7.22 (dd, $2 \mathrm{H}, J=7.13 \mathrm{~Hz}$, pyridine), 7.31-7.72 (m, 8H, phenyl), 7.75-7.88 (dd, 2H, J = 7.11 Hz, pyridine), 7.91-7.99 (m, 4H, phenyl); ${ }^{13} \mathrm{C}$ NMR (DMSO- $\left.d_{6}\right) \delta 52.3,59.1\left(4 \mathrm{C}, 4 \mathrm{CH}_{2}\right.$, morpholine), 93.8 (1C, $\mathrm{CH}$, methine proton), 116.2, 118.5, 122.6, 123.4, 124.3, 124.8, 126.4, 127.7, 129.4, 129.8, 131.4, 131.9, 132.4, 132.7, 146.2, 146.8, 147.6, 149.7, 161.9 (24C, Ar-C), 166.1, 168.5 (3C, three carbonyl groups); MS (70 ev, \%): $m / z=543\left(\mathrm{M}^{+}, 100 \%\right)$; Anal. Calc. (Found) for $\mathrm{C}_{32} \mathrm{H}_{25} \mathrm{~N}_{5} \mathrm{O}_{4}$ (543.58): $\mathrm{C}, 70.71$ (70.78); H, 4.64 (4.57); N, 12.88 (12.80).

\subsection{Synthesis of 2-(1-(Morpholino (Pyridin-4-yl) Methyl)-2-Oxoindolin-3-Ylidene) Hydrazine-1-Carbothioamide (14)}

To a warm mixture of thiosemicarbazide $(0.91 \mathrm{~g}, 0.01 \mathrm{~mol})$ in glacial acetic acid $(30 \mathrm{~mL})$, 1-(morpholino (pyridine) methyl) indoline-2,3-dione 2 (3.23 g, $0.01 \mathrm{~mol}$ ) was added. The reaction mixture was heated under reflux for $\sim 5-7 \mathrm{~h}$. The formed solid precipitate was filtered off, washed with ethanol / water and dried, then recrystallized from DMF to obtain yellow crystals in good yield (84\%), with m. p. $>350{ }^{\circ} \mathrm{C}$ (dec.). IR ( $\left.v, \mathrm{~cm}^{-1}\right) \mathrm{KBr}: 3430,3320$ $\left(\mathrm{NH}_{2}\right.$ and $\left.\mathrm{NH}\right), 3052(\mathrm{CH}$, aryl $), 2943(\mathrm{CH}$, aliph), $1678(\mathrm{C}=\mathrm{O}), 1629(\mathrm{C}=\mathrm{N}), 1582(\mathrm{C}=\mathrm{C})$, and 1475 (C=S); ${ }^{1} \mathrm{H}$ NMR (DMSO-d6, ppm) $\delta$ 2.72-3.13 (m, 8H, morpholine), 6.61 (s,1H, methine proton), 6.90 (br., 2H, $\mathrm{NH}_{2}, \mathrm{D}_{2} \mathrm{O}$ exchangeable), 7.22-7.50 (m, 4H, phenyl), 7.61-7.70 (dd, $2 \mathrm{H}, J=7.17 \mathrm{~Hz}$, pyridine), 7.77-7.90 (dd, 2H, $J=7.14 \mathrm{~Hz}$, pyridine), 11.35 (br., $1 \mathrm{H}, \mathrm{NH}, \mathrm{D}_{2} \mathrm{O}$ exchangeable); ${ }^{13} \mathrm{C}$ NMR (DMSO- $\left.d_{6}\right) \delta 51.4,59.9\left(4 \mathrm{C}, 4 \mathrm{CH}_{2}\right.$, morpholine), $94.5(1 \mathrm{C}, \mathrm{CH}$, methine proton), 116.9, 118.3, 124.1, 124.6, 129.2, 131.5, 132.1, 145.9, 147.1, 149.6 (12C, Ar-C), 165.1 (1C, carbonyl group), $178.8(1 \mathrm{C}, \mathrm{C}=\mathrm{S}) ; \mathrm{MS}(70 \mathrm{ev}, \%): m / z=396\left(\mathrm{M}^{+}, 100 \%\right)$; Anal. Calc. (Found) for $\mathrm{C}_{19} \mathrm{H}_{20} \mathrm{~N}_{6} \mathrm{O}_{2} \mathrm{~S}$ (396.47): C, 57.56 (57.65); H, 5.08 (5.02); N, 21.20 (21.14).

\subsection{Synthesis of 1- (Morpholino (Pyridin-4-yl) Methyl)-5'-Thioxospiro [Indoline-3,3'-[1,2,4] Triazolidin]-2-One (15)}

Method A: Compound 14 (3.96 g, $0.01 \mathrm{~mol})$ was stirred under reflux in dry chloroform $(35 \mathrm{~mL})$ or glacial acetic acid $(30 \mathrm{~mL})$, and triethylamine $(1 \mathrm{~mL})$ was added, as a catalyst for a long time $(\sim 15-17 \mathrm{~h})$ under TLC control. The mixture was evaporated under reduced pressure. The precipitate produced was washed many times with methanol and crystallized form dioxane to produce (15) in high yields. Method B: This was a one-pot synthesis method. A mixture of thiosemicarbazide $(0.91 \mathrm{~g}, 0.01 \mathrm{~mol})$ in glacial acetic acid $(40 \mathrm{~mL})$ and compound $2(3.23 \mathrm{~g}, 0.01 \mathrm{~mol})$ was formed. The reaction solution was heated and under reflux for a long time ( 19-21 h) under control (TLC). The final precipitate was filtered off, washed with ethanol/water and dried, then recrystallized from dioxane to obtain yellowish crystals in good yield (78\%), with m. p. $>350{ }^{\circ} \mathrm{C}$ (dec.). IR $\left(v, \mathrm{~cm}^{-1}\right) \mathrm{KBr}: 3350-3230(3 \mathrm{NH})$, $3060(\mathrm{CH}$, aryl $), 2950(\mathrm{CH}$, aliph), $1688(\mathrm{C}=\mathrm{O}), 1633(\mathrm{C}=\mathrm{N}), 1585(\mathrm{C}=\mathrm{C})$, and $1450(\mathrm{C}=\mathrm{S})$; ${ }^{1} \mathrm{H}$ NMR (DMSO-d6, ppm) $\delta$ 2.70-3.11 (m, 8H, morpholine), 6.64 (s,1H, methine proton), 7.15-7.44 (m, 4H, phenyl), 7.55-7.65 (dd, 2H, J = 7.13 Hz, pyridine), 7.80-7.95 (dd, 2H, $J=7.16 \mathrm{~Hz}$, pyridine), 10.10 (br., $1 \mathrm{H}, \mathrm{NH}, \mathrm{D}_{2} \mathrm{O}$ exchangeable), 10.40 (br., $1 \mathrm{H}, \mathrm{NH}, \mathrm{D}_{2} \mathrm{O}$ exchangeable), 11.55 (br., $1 \mathrm{H}, \mathrm{NH}, \mathrm{D}_{2} \mathrm{O}$ exchangeable); ${ }^{13} \mathrm{C} \mathrm{NMR}$ (DMSO- $\left.d_{6}\right) \delta 51.8,60.2(4 \mathrm{C}$, $4 \mathrm{CH}_{2}$, morpholine), 93.7 (1C, $\mathrm{CH}$, methine proton), 97.1 (1C, $5^{\prime}$-thioxospiro[indoline- 3, $3^{\prime}$ [1,2,4]triazolidin]-2-one), 117.8, 123.1, 124.5, 128.3, 130.6, 136.8, 145.4, 147.5, 149.5 (11C, 
Ar-C), 168.2 (1C, carbonyl group), 180.4 (1C,C=S); MS (70 ev, \%): m/z= $396\left(\mathrm{M}^{+}, 94 \%\right)$; Anal. Calc. (Found) for $\mathrm{C}_{19} \mathrm{H}_{20} \mathrm{~N}_{6} \mathrm{O}_{2} \mathrm{~S}$ (396.47): C, 57.56 (57.48); H, 5.08 (5.14); N, 21.20 (21.27).

3.16. Synthesis of 5'-Amino-1-(Morpholino (Pyridin-4-yl) Methyl) -3'H-Spiro [Indoline-3,2'-[1,3,4] Thiadiazol]-2-One (16)

A mixture of compound $14(3.96 \mathrm{~g}, 0.01 \mathrm{~mol})$, iodine $(1.26 \mathrm{~g}, 0.01 \mathrm{~mol})$ and anhydrous potassium carbonate $(1.4 \mathrm{~g}, 0.01 \mathrm{~mol})$ was stirred under reflux in dry 1,4-dioxane $(40 \mathrm{~mL})$ or dimethylformamide $(40 \mathrm{~mL})$, for $~ 13-15 \mathrm{~h}$ under TLC control. The solution was evaporated under reduced pressure. After drying, the precipitate produced was washed with $5 \% \mathrm{Na}_{2} \mathrm{~S}_{2} \mathrm{O}_{3}(30 \mathrm{~mL})$ and extracted from mixture of $\mathrm{CH}_{2} \mathrm{Cl}_{2} / \mathrm{MeOH}(10: 1,10 \mathrm{~mL} \times 4)$. The final precipitate was dried over anhydrous sodium sulphate and was purified using petroleum ether/ethyl-acetate mixture as eluent by silica gel column chromatography, yielding the synthesis of conforming analogs (16). Method B: A solution of 14 (3.96 g, $0.01 \mathrm{~mol})$ and triethylamine ( 3 drops) in ethanol $(30 \mathrm{~mL}$ ) was heated under reflux for $6-8 \mathrm{~h}$ with TLC control. After cooling, the solid precipitate was collected and crystallized from dioxane to produce yellow crystals in good yield $(76 \%)$, with m. p. $>350{ }^{\circ} \mathrm{C}$ (melted). IR $\left(v, \mathrm{~cm}^{-1}\right)$ KBr: 3420, $3335\left(\mathrm{NH}_{2}\right.$ and $\left.\mathrm{NH}\right), 3066(\mathrm{CH}$, aryl), $2957(\mathrm{CH}, \operatorname{aliph}), 1682(\mathrm{C}=\mathrm{O}), 1631(\mathrm{C}=\mathrm{N})$, 1583 (C=C); ${ }^{1} \mathrm{H}$ NMR (DMSO-d6, ppm) $\delta$ 2.68-3.10 (m, 8H, morpholine), 6.60 (s,1H, methine proton), 6.85 (br., $2 \mathrm{H}, \mathrm{NH}_{2}, \mathrm{D}_{2} \mathrm{O}$ exchangeable), 7.22-7.51 (m, 4H, phenyl), 7.61-7.75 (dd, $2 \mathrm{H}, J=7.18 \mathrm{~Hz}$, pyridine), 7.78-7.93 (dd, 2H, $J=7.17 \mathrm{~Hz}$, pyridine), 10.25 (br., $1 \mathrm{H}, \mathrm{NH}$, $\mathrm{D}_{2} \mathrm{O}$ exchangeable); ${ }^{13} \mathrm{C}$ NMR (DMSO- $\left.d_{6}\right) \delta 52.4,61.7\left(4 \mathrm{C}, 4 \mathrm{CH}_{2}\right.$, morpholine), 78.5 (1C, $3^{\prime} \mathrm{H}$-spiro[indoline-3,2' -[1,3,4] thiadiazol]-2-one), 91.6 (1C, $\mathrm{CH}$, methine proton), 118.2, 124.3, 124.7, 127.9, 128.5, 130.4, 145.1, 146.7, 149.3, 149.9 (12C, Ar-C), 167.5 (1C, carbonyl group); MS (70 ev, \%): $m / z=396\left(\mathrm{M}^{+}, 90 \%\right)$; Anal. Calc. (Found) for $\mathrm{C}_{19} \mathrm{H}_{20} \mathrm{~N}_{6} \mathrm{O}_{2} \mathrm{~S}$ (396.47): C, 57.56 (57.50); H, 5.08 (5.16); N, 21.20 (21.30).

3.17. Synthesis of 1-(Morpholino (Pyridin-4-yl) Methyl)-3-((2-Thioxo-2,3-Dihydro-1H-Imidazo [4,5-b] Quinoxalin-1-yl) Imino) Indolin-2-One (17)

A mixture of compound $14(3.96 \mathrm{~g}, 0.01 \mathrm{~mol})$ and 2, 3-dichloroquinoxaline (1.99 $\mathrm{g}$, $0.01 \mathrm{~mol})$ in absolute ethanol containing $(0.2 \mathrm{~mL})$ of triethylamine as a catalyst was refluxed for 22-25 h under control (TLC). The reaction solution was cooled and the deposited solid was filtered off, dried and recrystallized from dimethylformamide to produce yellowish crystals in good yield (74\%), with m. p. $>350{ }^{\circ} \mathrm{C}$ (melted). IR $\left(v, \mathrm{~cm}^{-1}\right) \mathrm{KBr}: 3340(\mathrm{NH})$, 3075 (CH, aryl), $2970\left(\mathrm{CH}\right.$, aliph), $1686(\mathrm{C}=\mathrm{O}), 1634(\mathrm{C}=\mathrm{N}), 1587(\mathrm{C}=\mathrm{C}), 1480(\mathrm{C}=\mathrm{S}) ;{ }^{1} \mathrm{H}$ NMR (DMSO-d6, ppm) $\delta$ 2.75-3.18 (m, 8H, morpholine), 6.55 (s,1H, methine proton), 7.05-7.67 (m, 8H, phenyl), 7.70-7.80 (dd, 2H, $J=7.05 \mathrm{~Hz}$, pyridine), 7.85-7.98 (dd, 2H, $J=7.07 \mathrm{~Hz}$, pyridine), 10.60 (br., $1 \mathrm{H}, \mathrm{NH}, \mathrm{D}_{2} \mathrm{O}$ exchangeable); ${ }^{13} \mathrm{C}$ NMR (DMSO- $\left.d_{6}\right) \delta 52.7$, 61.9 (4C, 4CH, morpholine), 92.8 (1C, $\mathrm{CH}$, methine proton), 116.2, 118.5, 124.1, 124.4, 124.6, 124.8, 129.6, 130.4, 131.5, 134.2, 146.8, 147.1, 149.6, 153.4, (20 C, Ar-C), 166.2 (1C, carbonyl group), $175.1(1 \mathrm{C}, \mathrm{C}=\mathrm{S}) ; \mathrm{MS}(70 \mathrm{ev}, \%): m / z=522\left(\mathrm{M}^{+}, 97 \%\right)$; Anal. Calc. (Found) for $\mathrm{C}_{27} \mathrm{H}_{22} \mathrm{~N}_{8} \mathrm{O}_{2} \mathrm{~S}$ (522.59): C, 62.06 (62.12); H, 4.24 (4.18); N, 21.44 (21.52).

\subsection{Pharmacological Screening}

\subsubsection{Ethics Approval and Consent to Participate}

No humans or animals were used in this study; nevertheless, all the procedures were carried out under the Medical Research Ethics Committee of Mansoura University, Faculty of Pharmacy, Department of Pharmacognosy, 35516, Egypt.

\subsubsection{Human and Animal Rights}

No humans or animals were used in the study. The research was conducted according to ethical standards in vitro. 


\subsubsection{Chemicals and Drugs}

Types of human carcinoma cancer cell line (MGC-803, MCF-7, CNE2 and KB) are derived from the National Cancer Institute, Cairo University, Cairo, Egypt, and 5-Fluorouracil and DMSO were purchased from Sigma-Aldrich (Saint Louis, MO, USA).

\subsubsection{Materials and Methods (In Vitro Cytotoxicity)}

The in vitro cytotoxicity of the synthesized compounds against different cancer cell lines was measured with the MTT assay, in agreement with the method found in [22-33,54]. The MTT assay is based on the reduction of the soluble 3-(4,5-dimethyl-2-thiazolyl)-2,5diphenyl-2H-tetrazoliumbromide (MTT) into a blue-purple formazan product, mainly by mitochondrial reductase activity inside living cells. The cells used in the cytotoxicity assay were cultured in the suitable cell culture medium (RPMI 1640) supplemented with $10 \%$ fetal calf serum. Cells suspended in the medium $\left(2 Y^{\prime} 104 / \mathrm{mL}\right)$ were plated in 96 -well culture plates and incubated at $37^{\circ} \mathrm{C}$ in a $5 \% \mathrm{CO}_{2}$ incubator. After $12 \mathrm{~h}$, the test sample $(2 \mathrm{~mL})$ was added to the cells $\left(2 \mathrm{Y}^{\prime} 104\right)$ in 96 -well plates and cultured at $37^{\circ} \mathrm{C}$ for 3 days. The cultured cells were mixed with $20 \mathrm{~mL}$ of MTT solution and incubated for $4 \mathrm{~h}$ at $37^{\circ} \mathrm{C}$. The supernatant was carefully removed from each well, and $100 \mathrm{~mL}$ of DMSO was added to each well to dissolve the formazan crystals, which were formed by the cellular reduction of MTT. After mixing with a mechanical plate mixer, the absorbance of each well was measured by a microplate reader using a test wavelength of $570 \mathrm{~nm}$. The results were expressed as the $\mathrm{IC}_{50}$, which is the concentration of the drugs inducing a $50 \%$ inhibition of cell growth of treated cells, when compared to the growth of control cells. Each experiment was performed at least three times. There was good reproducibility between replicate wells with standard errors below $10 \%$. Each experiment was repeated on three different days and conducted in triplicate. The relative cell anti-proliferative was measured according to the following equation: $\%$ cytotoxicity $=(1-\mathrm{As} / \mathrm{Ab}) \times 100$, where $\mathrm{As}=$ absorbance of each sample and $\mathrm{Ab}=$ absorbance of the blank. The probity analysis using the SPSS software program (version 20, SPSS Inc., Chicago, IL, USA) was used to determine each $\mathrm{IC}_{50}$.

\section{Conclusions}

In this article, isatin derivatives (1-(morpholino (pyridin-4-yl) methyl) indoline-2,3dione) were converted into polyfunctionalized heterocycles with promising cytotoxic activity. Different derivatives were prepared, including 3-((bromophenyl) imino)-1- (morpholino (pyridine) methyl) indolinone, 2-((oxoindoline) amino) benzoic acid, 3-(thi- azoloimino) indolinone, ethyl-2-((oxoindoline) amino)-benzothiophene-3-carboxylate, 1- (oxoindoline)benzothieno[2,3-d]pyrimidinone, ethyl-2-(oxoindoline) hydrazine-1-carb- oxylate, $N$-(merca pto-pyrimidine)-2-(oxoindoline) hydrazine-1-carboxamide, $\mathrm{N}$-(thiazolo [3,2-a]pyrimidine)2-(oxoindoline) hydrazine-1-carboxamide, 3-((amino-phenyl) amino)-3-hydroxy-indolinone, 3-((amino-phenyl) imino)-indolinone, 2-(2-((oxoindoline) amino) phenyl) isoindolinone, 2-(oxoindoline) hydrazine-1-carbothioamide, $5^{\prime}$-thioxospiro[ind- oline-3, $3^{\prime}$-[1,2,4]triazolidin]one, $5^{\prime}$-amino-spiro [indoline-3,2'-[1,3,4] thiadiazol]-one and 3-((2-thioxo-imidazo[4,5b]quinoxaline)imino) indolinone in good yields. Isatin with imidazo [4, 5-b] quinoxaline, thiazolo [3,2-a] pyrimidine, hydrazine-1-carboxamide, spiro[indoline-3,2'-[1,3,4]thiadiazol]2-one, $5^{\prime}$-thioxospiro[indoline-3,3'-[1,2,4] triazolidin]-2-one moiety and substituted heteroatoms as nitrogen, oxygen and sulfur showed potent cytotoxic activity against the different types of human carcinoma cells lines (MGC-803, MCF-7, CNE2 and KB). The simplicity of the synthetic methods and the potent activity of the synthesized compounds render these derivatives interesting targets for future development as cytotoxic agents. So, the imidazo $[4,5-b]$ quinoxaline-imino- indolinone is a promising anticancer molecule with diverse effects, including angiopreventive and anti-proliferative effects, in addition to apoptosis-inducing effects. 


\begin{abstract}
Author Contributions: A.A.A.-H. And S.A.A.-H. Participated in the synthesis, purification and characterization of the new compounds; the Department of Pharmacognosy, Faculty of Pharmacy, Mansoura University, Egypt, participated in the evaluation of the newly synthesized compounds for anticancer activities. S.A.A.-H. participated in the work of physical and chemical experiments and some of the measurements for the prepared compounds, the interpretation of many results and the interpretation of spectroscopy of new compounds. A.A.A.-H. participated in the interpretation of the results, writing, revision and correspondence to the journal Molecules until the manuscript was accepted. All authors have read and agreed to the published version of the manuscript.
\end{abstract}

Funding: This research received no external funding.

Institutional Review Board Statement: Not applicable.

Informed Consent Statement: Not applicable.

Data Availability Statement: All data are contained within the article and the experimental section.

Acknowledgments: The authors are extremely grateful to Farid A. Badria and the Department of Pharmacognosy, Faculty of Pharmacy, Mansoura University, 35516 Egypt, for helping us to screen the newly synthesized compounds for anticancer activity.

Conflicts of Interest: The authors declare no conflict of interest.

Sample Availability: Samples of the synthesized compounds are available from the authors.

\title{
References
}

1. Sagar, S.; Esau, L.; Moosa, B.; Khashab, N.M.; Bajic, V.B.; Kaur, M. Cytotoxicity and apoptosis induced by a plumbagin derivative in estrogen positive MCF-7 breast cancer cells. Anti-Cancer Agents Med. Chem. 2014, 14, 170-180. [CrossRef] [PubMed]

2. Plackal, B.; George, A.; Abrahamse, H. A review on novel breast cancer therapies: Photodynamic therapy and plant derived agent induced cell death mechanisms. Anti-Cancer Agents Med. Chem. 2016, 16, 793-801. [CrossRef] [PubMed]

3. Medvedev, A.; Buneeva, O.; Gnedenko, O.; Ershov, P.; Ivanov, A. Isatin, an endogenous nonpeptide biofactor: A review of its molecular targets, mechanismsof actions, and their biomedical implications. BioFactors 2018, 44, 95-108. [CrossRef] [PubMed]

4. Rana, S.; Blowers, E.C.; Tebbe, C.; Contreras, J.I.; Radhakrishnan, P.; Kizhake, S.; Zhou, T.; Rajule, R.N.; Arnst, J.; Munkarah, A.R.; et al. Isatin derived spirocyclic analogs with $\alpha$-methylene- $\gamma$-butyrolactone as anticancer agents: A structure activity relationship study. J. Med. Chem. 2016, 59, 5121-5127. [CrossRef]

5. Abo-Salem, H.M.; Nassrallah, A.; Soliman, A.A.F.; Ebied, M.S.; Elawady, M.E.; Abdelhamid, S.A.; El-Sawy, E.R.; Al-Sheikh, Y.A.; Aboul-Soud, M.A.M. Synthesis and bioactivity assessment of novel spiro pyrazole-oxindole congeners exhibiting potent and selective in vitro anticancer effects. Molecules 2020, 25, 1124. [CrossRef] [PubMed]

6. Lin, W.J.; Shia, K.S.; Song, J.S.; Wu, M.H.; Li, W.T. Synthesis of (E)-oxindolylidene acetate using tandem palladium-catalyzed Heck and alkoxycarbonylation reactions. Org. Biomol. Chem. 2016, 14, 220-228. [CrossRef]

7. Singh, A.; Raghuwanshi, K.; Patel, V.K.; Jain, D.K.; Veerasamy, R.; Dixit, A.; Rajak, H. Assessment of 5-substituted isatin as surface recognition group: Design, synthesis, and anti-proliferative evaluation of hydroxamates as novel histone deacetylase inhibitors. Pharm. Chem. J. 2017, 51, 366-374. [CrossRef]

8. Varun, C.; Sonam, N.; Kakkar, R. Isatin and its derivatives: A survey of recent syntheses, reactions, and applications. Med. Chem. Commun. 2019, 10, 351-368. [CrossRef]

9. Webber, S.E.; Tikhe, J.; Worland, S.T.; Fuhrman, S.A.; Hendrickson, T.F.; Matthews, D.A.; Love, R.A.; Patick, A.K.; Meador, J.W.; Ferre, R.A.; et al. Design, synthesis, and evaluation of nonpeptidic inhibitors of human rhinovirus 3C protease. J. Med. Chem. 1996, 39, 5072-5082. [CrossRef]

10. Quenelle, D.C.; Keith, K.A.; Kern, E.R. In vitro and in vivo evaluation of isatin-beta-thiosemicarbazone and marboran against vaccinia and cowpox virus infections. Antivir. Res. 2006, 71, 24-30. [CrossRef]

11. De Clercq, E. Historical perspectives in the development of antiviral agents against poxviruses. Viruses 2010, 2, 1322-1339. [CrossRef] [PubMed]

12. Zhou, L.; Liu, Y.; Zhang, W.; Wei, P.; Huang, C.; Pei, J.; Yuan, Y.; Lai, L. Isatin compounds as noncovalent SARS coronavirus 3Clike protease inhibitors. J. Med. Chem. 2006, 49, 3440-3443. [CrossRef] [PubMed]

13. Liu, W.; Zhu, H.M.; Niu, G.J.; Shi, E.Z.; Chen, J.; Sun, B.; Chen, W.Q.; Zhou, H.G.; Yang, C. Synthesis, modification and docking studies of 5-sulfonyl isatin derivatives as SARS-CoV 3C-like protease inhibitors. Bioorg. Med. Chem. 2014, 22, 292-302. [CrossRef] [PubMed]

14. Ronen, D.; Sherman, L.; Bar-Nun, S.; Teitz, Y. N-methylisatin-beta-4' , $^{\prime}$-diethylthiosemi-carbazone, an inhibitor of moloney leukemia virus protein production: Characterization and in vitro translation of viral mRNA. Antimicrob. Agents Chemother. 1987, 31, 1798-1802. [CrossRef]

15. Meleddu, R.; Distinto, S.; Corona, A.; Tramontano, E.; Bianco, G.; Melis, C.; Cottiglia, F.; Maccioni, E. Isatin thiazoline hybrids as dual inhibitors of HIV-1 reverse transcriptase. J. Enzyme Inhib. Med. Chem. 2017, 32, 130-136. [CrossRef] 
16. Zhang, H.M.; Dai, H.; Hanson, P.J.; Li, H.; Guo, H.; Ye, X.; Hemida, M.G.; Wang, L.; Tong, Y.; Qiu, Y.; et al. Antiviral activity of an isatin derivative via induction of PERK-Nrf2-mediated suppression of cap-independent translation. ACS Chem. Biol. 2014, 9, 1015-1024. [CrossRef]

17. Mishra, P.; Kumar, A.; Mamidi, P.; Kumar, S.; Basantray, I.; Saswat, T.; Das, I.; Nayak, T.K.; Chattopadhyay, S.; Subudhi, B.B.; et al. Inhibition of chikungunya virus replication by 1-[(2-methylbenzimidazol-1-yl) methyl]-2-oxo-indolin-3-ylidene] amino] thiourea (MBZM-N-IBT). Sci. Rep. 2016, 6, 20122. [CrossRef]

18. Aboul-Fadl, T.; Abdel-Hamid, M.K.; Youssef, A.F. Schiff bases of indoline-2, 3-dione (isatin) derivatives as efficient agents against resistant strains of mycobacterium tuberculosis. Der Pharma Chem. 2015, 7, 217-225.

19. Hu, Y.Q.; Meng, L.D.; Qiang, M.; Song, X.F. Design, Synthesis, and in vitro anti-mycobacterial evaluation 1H-1, 2, 3-triazoletethered ciprofloxacin and isatin conjugates. J. Heterocycl. Chem. 2017, 54, 3725-3729. [CrossRef]

20. Karthik, R.; Vimaladevi, G.; Chen, S.M.; Elangovan, A.; Jeyaprabha, B.; Prakash, P. Corrosion inhibition and adsorption behavior of 4-amino acetophenone pyridine 2-aldehyde in 1M hydrochloric acid. Int. J. Electrochem. Sci. 2015, 10, 4666-4681.

21. Ansari, K.R.; Quraishi, M.A. Experimental and quantum chemical evaluation of schiff bases of isatin as a new and green corrosion inhibitors for mild steel in $20 \% \mathrm{H}_{2} \mathrm{SO}_{4}$. J. Taiwan Inst. Chem. Eng. 2015, 54, 145-154. [CrossRef]

22. Abu-Hashem, A.A.; El Shehry, M.F.; Badria, F.A. Design and synthesis of novel thiophenecarbohydrazide, thienopyrazole and thienopyrimidine derivatives as antioxidant and antitumor agents. Acta Pharm. 2010, 60, 311-323. [CrossRef] [PubMed]

23. Gouda, M.A.; Abu-Hashem, A.A. Synthesis, characterization, antioxidant and antitumor evaluation of some new thiazolidine and thiazolidinone. Arch. Pharm. Chem. Life Sci. 2011, 11, 170-177. [CrossRef]

24. Abu-Hashem, A.A.; Youssef, M.M.; Hussein, H.A.R. Synthesis, antioxidant, antitumor activities of some new thiazolo pyrimidines, pyrrolothiazolopyrimidines and triazolopyrrolothiazolopyrimidines derivatives. J. Chin. Chem. Soc. 2011, 58, 41-48. [CrossRef]

25. Abu-Hashem, A.A.; Aly, A.S. Synthesis of new pyrazole, triazole, thiazolidine,-pyrimido [4,5-b] quinoline derivatives with potential antitumor activity. Arch. Pharmacal Res. 2012, 35, 437-445. [CrossRef]

26. Abu-Hashem, A.A.; Badria, F.A. Design, Synthesis of novel thiourea and pyrimidine derivatives as potential antitumor agents. $J$ Chin. Chem. Soc. 2015, 62, 506-512. [CrossRef]

27. Abu-Hashem, A.A.; Hussein, H.A.R. Synthesis and antitumor activity of new pyrimidine and caffeine derivatives. Lett. Drug Des. Discov. 2015, 12, 471-478. [CrossRef]

28. Abu-Hashem, A.A.; El-Shazly, M. Synthesis of new quinoxaline, pyrimidine, and pyrazole furochromone derivatives as cytotoxic agents. Mon. Chem. 2017, 148, 1853-1863. [CrossRef]

29. Abu-Hashem, A.A.; Aly, A.S. Chemistry of new dimethyl-benzo,-1, 3, 6-oxadiazepine and 1, 3, 5-triazepine derivatives as anticancer agents. Synth. Commun. 2017, 47, 2417-2425. [CrossRef]

30. Abu-Hashem, A.A.; Gouda, M.A.; Badria, F.A. Design, synthesis and identification of novel substituted isothiochromene analogs as potential antiviral and cytotoxic agents. Med. Chem. Res. 2018, 27, 2297-2311. [CrossRef]

31. Abu-Hashem, A.A.; Abu-Zied, K.M.; Zaki, M.E.A.; El-Shehry, M.F.; Awad, H.M.; Khedr, M.A. Design, synthesis, and anticancer potential of the enzyme (PARP-1) inhibitor with computational studies of new triazole, thiazolidinone,-thieno [2, 3-d] pyrimidinones. Lett. Drug Des. Discov. 2020, 17, 799-819. [CrossRef]

32. Abu-Hashem, A.A. Synthesis of new pyrazoles, oxadiazoles, triazoles, pyrrolotriazines and pyrrolotriazepines as potential cytotoxic agents. J. Heterocycl. Chem. 2021, 58, 805-821. [CrossRef]

33. Abu-Hashem, A.A.; Al-Hussain, S.A.; Zaki, M.E.A. Design, synthesis and anticancer activity of new polycyclic: Imidazole, thiazine, oxathiine, pyrrolo-quinoxaline and thienotriazolopyrimidine derivatives. Molecules 2021, 26, 2031. [CrossRef] [PubMed]

34. Abu-Hashem, A.A. Synthesis and reaction of novel spiro-pyrimidine derivatives. J. Heterocycl. Chem. 2014, 51, 1020-1026. [CrossRef]

35. Abu-Hashem, A.A.; El-Shazly, M. Synthesis and antimicrobial evaluation of novel triazole, tetrazole, and spiropyrimidinethiadiazole derivatives. Polycycl. Aromat. Compd. 2021, 41, 478. [CrossRef]

36. Abu-Hashem, A.A.; Youssef, M.M. Synthesis of new visnagen and khellin furochromone pyrimidine derivatives and their anti-inflammatory and analgesic activity. Molecules 2011, 16, 1956-1972. [CrossRef]

37. Abu-Hashem, A.A. Synthesis of new furothiazolo pyrimido quinazolinones from visnagenone or khellinone and antimicrobial activity. Molecules 2018, 23, 2793. [CrossRef] [PubMed]

38. Abu-Hashem, A.A.; Al-Hussain, S.A.; Zaki, M.E.A. Synthesis of novel benzodifuranyl; 1, 3, 5-triazines; 1, 3, 5-oxadiazepines; and thiazolopyrimidines derived from visnaginone and khellinone as anti- inflammatory and analgesic agents. Molecules 2020, 25, 220. [CrossRef]

39. Abu-Hashem, A.A.; Abu-Zied, K.M.; El-Shehry, M.F. Synthetic utility of bifunctional thiophene derivatives and antimicrobial evaluation of the newly synthesized agents. Mon. Chem. 2011, 142, 539-545. [CrossRef]

40. Abu-Hashem, A.A.; Hussein, H.A.R.; Abu-zied, K.M. Synthesis of novel 1, 2, 4-triazolopyrimidines and their evaluation as antimicrobial agents. Med. Chem. Res. 2016, 26, 120-130. [CrossRef]

41. Abu-Hashem, A.A.; Gouda, M.A. Synthesis and antimicrobial activity of some novel quinoline, chromene, pyrazole derivatives bearing triazolopyrimidine moiety. J. Heterocycl. Chem. 2017, 54, 850-858. [CrossRef]

42. Abu-Hashem, A.A. Synthesis and biological activity of pyrimidines, quinolines, thiazines and pyrazoles bearing a common thieno moiety. Acta Pol. Pharm. Drug Res. 2018, 75, 59-70. 
43. Abu-Hashem, A.A.; Faty, R.A.M. Synthesis, antimicrobial evaluation of some new 1, 3, 4-thiadiazoles and 1, 3, 4-thiadiazines. Curr. Org. Synth. 2018, 15, 1161-1170. [CrossRef]

44. Abu-Hashem, A.A.; Fathy, U.; Gouda, M.A. Synthesis of 1, 2, 4-triazolopyridazines, isoxazolofuropyridazines, and Tetrazolopyridazines as antimicrobial agents. J. Heterocycl. Chem. 2020, 57, 3461-3474.

45. Abu-Hashem, A.A.; Hussein, H.A.R.; Aly, A.S. Synthesis and antimicrobial activity of novel 1,2,4-triazolopyrimidofuro- quinazolinones from natural furochromones (visnagenone and khellinone). Med. Chem. 2021, 17, 707-723. [CrossRef] [PubMed]

46. Abu-Hashem, A.A. Synthesis and antimicrobial activity of new 1, 2, 4-triazole, 1, 3, 4-oxadiazole, 1, 3, 4-thiadiazole, thiopyrane, thiazolidinone and azepine derivatives. J. Heterocycl. Chem. 2021, 58, 74-92. [CrossRef]

47. Abu-Hashem, A.A.; Zaki, M.E.A. Direct amination and synthesis of fused N-substituted isothiochromene derivatives. J. Heterocycl. Chem. 2019, 56, 886-894. [CrossRef]

48. Abu-Hashem, A.A.; El-Shazly, M. Synthesis of new isoxazole-, pyridazine-, pyrimido- pyrazines and their anti-inflammatory and analgesic activity. Med. Chem. 2018, 14, 356-371. [CrossRef]

49. Abu-Hashem, A.A.; Gouda, M.A.; Badria, F.A. Synthesis of some new pyrimido [2', 1': 2, 3] thiazolo [4, 5-b] quinoxaline derivatives as anti-inflammatory and analgesic agents. Eur. J. Med. Chem. 2010, 45, 1976-1981. [CrossRef]

50. El-Gazzar, A.B.A.; Youssef, A.M.S.; Youssef, M.M.; Abu-Hashem, A.A.; Badria, F.A. Design and synthesis of azolopyrimidoquinolines, pyrimidoquinazolines as anti-oxidant, anti-inflammatory and analgesic activities. Eur. J. Med. Chem. 2009, 44, 609-624. [CrossRef]

51. Pandeya, S.N.; Yogeeswari, P.; Sriram, D.; De Clercq, E.; Pannecouque, C.; Witvrouw, M. Synthesis and screening for anti-HIV activity of some $N$-Mannich bases of isatin derivatives. Chemotherapy 1999, 45, 192-196. [CrossRef] [PubMed]

52. Pandeya, S.N.; Sriram, D.; Nath, G.; De Clercq, E. HIV evaluation of schiff and Mannich bases of isatin and its derivatives with triazole. Arzneimit-Telforschung 2000, 50, 55-59.

53. Pandeya, S.N.; Sriram, D.; Nath, G.; Declercq, E. Synthesis, antibacterial, antifungal and anti-HIV activities of schiff and Mannich bases derived from isatin derivatives and $\mathrm{N}$-[4-(4'-chlorophenyl)thiazol-2-yl]thiosemicarbazide. Eur. J. Pharm. Sci. 1999, 9, 25-31. [CrossRef]

54. Mosmann, T. Rapid colorimetric assay for cellular growth and survival: Application to proliferation and cytotoxicity assays. J. Lmmunological Methods 1983, 65, 55-63. [CrossRef]

55. De Paiva, R.E.F.; Vieira, E.G.; Da Silva, D.R.; Wegermann, C.A.; Ferreira, A.M.C. Anticancer compounds based on isatinderivatives: Strategies to ameliorate selectivity and efficiency. Front. Mol. Biosci. 2021, 7, 627272. [CrossRef] 